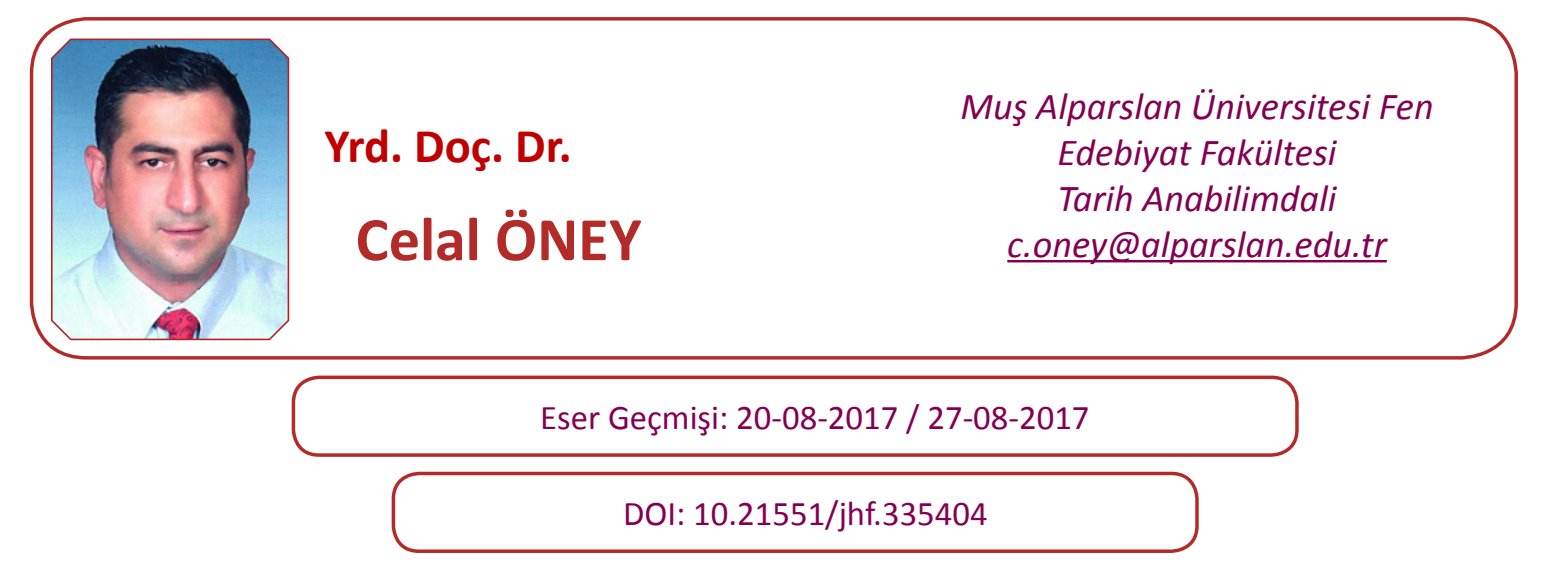

\title{
Arabistan Protestan Misyonunun Gelişiminde Kadın Misyonerlerin Rolü
}

\section{The Role of Female Missionaries in the Develeopment of the Arabian Protestant Mission}

\section{ÖZET}

$\mathrm{Bu}$ çalışmamızda Arabistan yarımadasında Amerikan Protestan misyonerlik faaliyetlerinde kadın misyonerin konumunu incelemeye çalıştık. Arabistan misyonuna katılan kadın misyonerlerin sahip olduğu özelliklere göre üç bölüme ayırdığımız konunun ilk bölümünde misyona katılan misyoner eşlerinin misyonun bölgede yer edinmesi ve yerel kadınlar arasındaki faaliyetlerine değindik. İkinci bölümde ise bekâr bayan misyonerlerin misyona katılımını irdeleyerek Arabistan misyonunun sağlı alanına yoğunlaşmasını ve yerel kız çocuklarının eğitimine verdikleri önemi tartıştık. Araştırmamızın üçüncü bölümünde ise Profesyonel bayan misyonerlerin misyon tarafından nasıl ve hangi amaçlar doğrultusunda istihdam edildiğini vurgulayarak Petrol zenginliği ile gelişen bölgenin misyonun yapısına ve faaliyetlerine nasıl yansıdığının üzerinde durduk. Son olarak çalışmamızın sonuç bölümünde, Arabistan misyonunun Protestanlığa adam kazandırma mücadelesinde neden başarısız olduğunu fakat Arap kadının sosyal, kültürel ve toplum içindeki statüsünün artmasında ve şekillenmesinde nasıl başarılı olduklarına değindik.

Anahtar Kelimeler: Arabistan Misyonu, Protestanlık, Amerikan Misyonerlik Faaliyetleri

\section{ABSTRACT}

In our research we tried to inquire the place of women missionaries in the American Protestant missionary movement in the Arabian peninsula. We divided the subject as three periods according to the women missionaries who worked for the mission, their marital status and profession. In the first part, the role of missionary wives in Protestant missionary activities among indigenous women and girls of Arabia and the effort of formulating the mission structure and development in the peninsula. In the second part, it was debated that how and why single female missionaries started to join the mission and why these missionaries intensively improved mission's health care service in the region and also turned their faces to the education of young girls. 
At the third part of the research, it was analyzed that way and with what kind of targets that the missionary organization decided to employ professional women missionaries and what is more, how oil investments changed the economic climate of the region and the impact of this oil richness on the missionary activities. Finally, the reasons that coursed the failure of the mission about conversion was taken into inquire and also the success of the mission on increasing the women's statue in the Arabian society, culture and traditions.

Keywords: Arabian Mission, Protestantism, American Missionary Activities.

\section{Giriş}

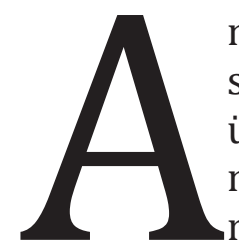

merikan Protestan misyonerlik faaliyetlerinin Osmanlı topraklarından sonra Arabistan körfezine doğru yayılmaya başlaması, bu bölgede bulunan ülkelerin Protestan misyonerlik faaliyetleri için gelecek vaat edebileceğinin misyonerler tarafından tespitiyle on dokuzuncu yüzyılın sonlarına doğru rastlamaktadır. İslam dinin merkezi olmasının yanında bu dinin peygamberi olarak kabul edilen Hz. Muhammed'in de doğum yeri olması hasebiyle Protestan misyonu açısından misyonerlerce mutlaka dokunulması gereken bir alan olarak değerlendirilen Arabistan yarımadasının, Protestanlığa olan gereksinimi ve bölgedeki halkların entelektüel aydınlanmaya olan ihtiyacı, Protestan misyonerlerce devamlı dile getirilerek misyonerlerin Arabistan yarımadasına yönelmesine neden oldu. Diğer taraftan Amerikalı Protestan kadın misyonerlerin de bölgeye olan ilgisinin artması ve bu ilgi sonucunda yarımadaya kadın misyonerlerin de gelip misyonun gelişmesinde önemli rol oynamasının nedeni ise bölgedeki kadınların içinde bulunduğu durumdan ileri gelmekteydi. Protestan misyonerlerin bakış açısıyla, Arabistan yarımadasında bulunan toplumlar içinde yaşayan kadın sınıfının devamlı bir şekilde erkek baskısı altında olması, entelektüel seviyesinin düşük olması ve sadece cinsel bir obje şeklinde yaklaşılması Amerikalı Protestan kadın misyonerleri, bu durumu tersine çevirmek için bölgeye gelmeye cezp eden önemli nedenler arasındaydı. Bu durum, Arabistan misyonunun erkek egemen yapısından sivrilip daha çok kadınları hedef alan bir misyon yapısına dönüşmesine ve erkek misyonerlere nazaran bölgede kadın misyonerlerin daha fazla görev üstlenmesine de sebebiyet verecekti. Arabistan yarımadasındaki kadınların devamlı olarak kapalı ortamlarda bulunması, Protestan erkek misyonerler tarafından verilen İncil vaazlarını kabul etmemesi, cehaletin getirdiği acı ile devamlı mücadele içinde olması ve en önemlisi sağlık hizmetlerinden yoksun oluşları Arap kadınlarını, Protestan kadın misyonerlerin gözünde ulaşılması gereken bir kitle şeklinde algılanmasına yol açarak misyonerler tarafından "putperest din kardeşlerine" ulaşmak ve onları doğru yol olan Hristiyanlığın gerçek versiyonu olarak misyonerlerce addedilen Protestanlığa yönlendirmek ancak ve ancak Hristiyan kadınlar tarafından geçekleştirilebilirdi ki onlarda Protestan kadın misyonerlerdi (Scudder, 1998: s.22/28). Arabistan yarımadasındaki ülkelerde yaşayan kadınların içinde bulundukları durumun, misyonerlerce abartılı ve ağdalı bir şekilde misyoner yazım hayatının ürünleri olan süreli yayınlarda bir propaganda aracı olarak dile getirilmesi özellikle Amerika'da bu bölgeye olan ilginin artmasına ve kadınların durumlarından dolayı özellikle de Arap kadınlarına Amerikan halkının acı içeren sempatisini artırmıştı. Bu ilgi ve sempati, Protestan misyonerlerin misyon sahasını genişletme ve bu sahaları okul, hastane ve atölyeler ile donatılması için ihtiyaç duyulan paranın Amerika'daki kiliselerin sandıklarına atılan bağışlara dönüşmesinin yanında Arabistan yarımadasında Hristiyanlığın canlandırılmaya çalıșılması fikri de bu bağışların devamlı bir şekilde artmasının ardında rol 
oynayan önemli bir faktördü (Windsor, 2002).

Amerikalı Protestan misyonerlerin Arap yarımadasında kurmayı tasarladıkları misyonunun genel dayanağını da yukarıda belirttiğimiz hususlara paralel olarak insani yardım ve sekülerleşme konularını ihtiva etmekteydi. Arabistan yarımadasında Protestan misyonu tarafından yapılacak olan sosyal hizmetleri, eğitim seferberliği ve sağlık alanında ihtiyaç duyulan hizmetler, bölgede Protestanlığı seçecek olan insanların hem bu dinde kalmasını sağlayacak önemli avantajlar meydana getireceği gibi aynı zamanda bu faaliyetlerden misyonerler tarafindan elde edilecek olan propaganda malzemesi Amerika'daki Protestan cemaatler arasında misyonunun devamı için gerekli maddi yardımın sağlanmasında önemli bir rol oynayacaktı (Dalyan, 2011: s. 345/346). Böylelikle Amerikalı Protestan erkek misyonerler Arabistan bölgesinde batı değerlerini Hristiyan paketi içinde sunmaya çalışırken bölgeye intikal edecek olan meslektaşları kadın misyonerler de bölgede kadınlar ile ilgilenerek tasvir ettikleri bu putperest coğrafyada kadınların sekülerleşmesi ve toplum içinde kimlik kazanması için mücadele ettiklerini gündemde tutarak adeta "kadın için kadın harekâtı” tarzında bir hareket ile Amerika'daki kadın destekçilerinin sayısını bir hayli artırmayı hedeflemekteydiler. Bu durum aynı zamanda Amerika'daki kadın sınıfının toplum içinde daha fazla öne çıkması adına bir strateji şeklinde de misyonerler tarafından sunulmaya çalışılacaktı (Al-Sayegh, 1998: s. 340/341).

Bu çalışma, Arabistan yarımadasında kurulan Protestan Amerikan misyoner hareketin oluşumundakadın misyonerlerinaktifbir rol üstlendiklerini ortaya koymaya çalışarakbölgenin toplumsal dönüşümünde özellikle kadın misyonerlerin nasıl birer öncü olduklarının altını çizmeye çalışacaktır. Arabistan misyonunun odak noktasına alınan toplumun kadın kesimi arasında sürdürülecek olan propaganda faaliyetleri, bu bölgedeki Amerikan misyonunun temel karakterini meydana getirerek misyonun asıl hedefinin saptanmasında ve şekillenmesinde nasıl etkili olduğu bu çalışmamızın diğer bir dayanak noktasını teşkil edecektir. Son olarak, çalışmamızda Arabistan misyonunda görev üstlenen kadın misyonerlerin nasıl kendi inanç ve çıkarlarını unutarak bunların ötesine geçip bölgedeki kadınların sahip oldukları statüyü artırmayı ve bu kadınların misyonerlerin belirttiği gibi içinde bulunduğu toplumsal baskıyı azaltmak için canla başla çalıştıklarını ortaya çıkarmaya çalışacağız. Arabistan misyonunda görevli olan kadın misyonerlerin, misyon sahasında yaşayan kadınlara ilham veren bir kaynak halini alması ve bu ilham ile kendine güveni gelen bölgedeki kadınların sosyal ve kültürel değişiklikleri tetikleyerek geleceklerini iyi yönde inşa etmenin mücadelesi içine girmesini sağlayan temel etmenlerin neler olduğunun incelenmesi çalışmamızın ana sorunsalı olacaktır.

Araştırmamızın kaynaklarını Arabistan yarımadasının çeşitli bölgelerinde Protestan misyonerlik faaliyeti içinde bulunan Amerikalı kadın misyonerlerin yazdığı günlükler ve tuttfukları hatıra notları, oluşturmaktadır. Bu misyoner kadınların kimler olduğuna baktığımızda ilk olarak öğretmen ve din görevlisi olan ve Amerikan misyonunun Arap bölgesinde genişlemesinde önemli görevler üstlenen Elizabeth Zwemer, doktor olarak görev üstlenen Eleanor Calverley, hemşire olarak misyonda çalışan Jeanette Boersma ve Cornelia Dalenberg ve yine doktor olarak misyonda çalışan Mary Bruins Allison adlı kadın misyonerlerin olduğunu görürüz. Erkek misyonerler kadar yeterli saha ve misyon tecrübesine sahip bu kadın misyonerlerin meydana getirdiği yayınlanmış rapor ve kitaplardan meydana gelen yazınsal literatür bize hem Protestan Amerikan misyonunun Arabistan yarımadasında nasıl kurumsallaştığı hakkında fikir verirken hem de yirminci yüzyıl boyunca Arap yaşamının 
nasıl bir süreçten geçtiği, yaşam koşullarının nasıl şekillendiği ve Arap kadının bu yüzyılda nasıl bir statü değişikliğine uğradığı hakkında aydınlatıcı ip uçları vermesinden dolayı önemlidir. Misyonerler tarafından üretilen bu literatürü önemli kılan bir diğer husus ise Arabistan yarımadasında yaşayan kadın nüfus hakkında nerdeyse hiç denebilecek bir yazınsal ürününün yerel araştırmacılar tarafından bu süreçte kaleme alınmamasından ileri gelmektedir. Protestan kadın misyonerlerce yazılan hatıra, günlük ve kitaplara ek olarak Umursanmayan Arabistan (Neglected Arabia) olarak bilinen Arabistan Misyon Dergisi (Journal of the Arabian Mission), Amerikan Protestan misyonun Arabistan yarımadasındaki faaliyetleri hakkında önemli bilgiler içermektedir.

\section{Arabistan Misyonunun oluşumundan önceki dönem}

Amerikalı Protestan misyonerlerin, Arap misyonunu kurması sonrasında yarımadaya gelen ilk misyonerlerin misyon sahasındaki halklar arasında yaptıkları gözlemler sonucunda elde ettikleri izlenimlerde Arap kadının, ailesi içerisinde önemli bir gücü olduğuna kanaat getirilmiști. Ailenin yapı merkezinde bulunan Arap kadınının, ailenin devamlılığı konusundaki yürütücü rolü ve çocuklar üzerindeki tartışmasız otoritesi, bölgeye gelen misyonerleri önemli ölçüde etkilemişti. 1922 yılında misyon sahasında görevli bir erkek misyonerin yaptığı bir gözlem Arap kadının rolünü şöyle betimlemektedir. "Gerçek şu ki, Müslüman bir annenin hem kız çocukları üzerinde hem de erkek çocukları üzerinde büyük bir etkisi vardır ve bu etki, çocukların on yaşına ulaştığı dönemde en tepe zirvesine ulaşır. Bu nedenle İslam dini altında bulunan bu topraklarda Protestan dinin yayılmasını hızlandırmak istiyorsak Müslüman kadınlar arasında yürüteceğimiz propaganda faaliyetlerine hem önem vermeliyiz hem de oldukça da ciddiye almalıyız (Al-Sayegh, 1998: s. 340)".

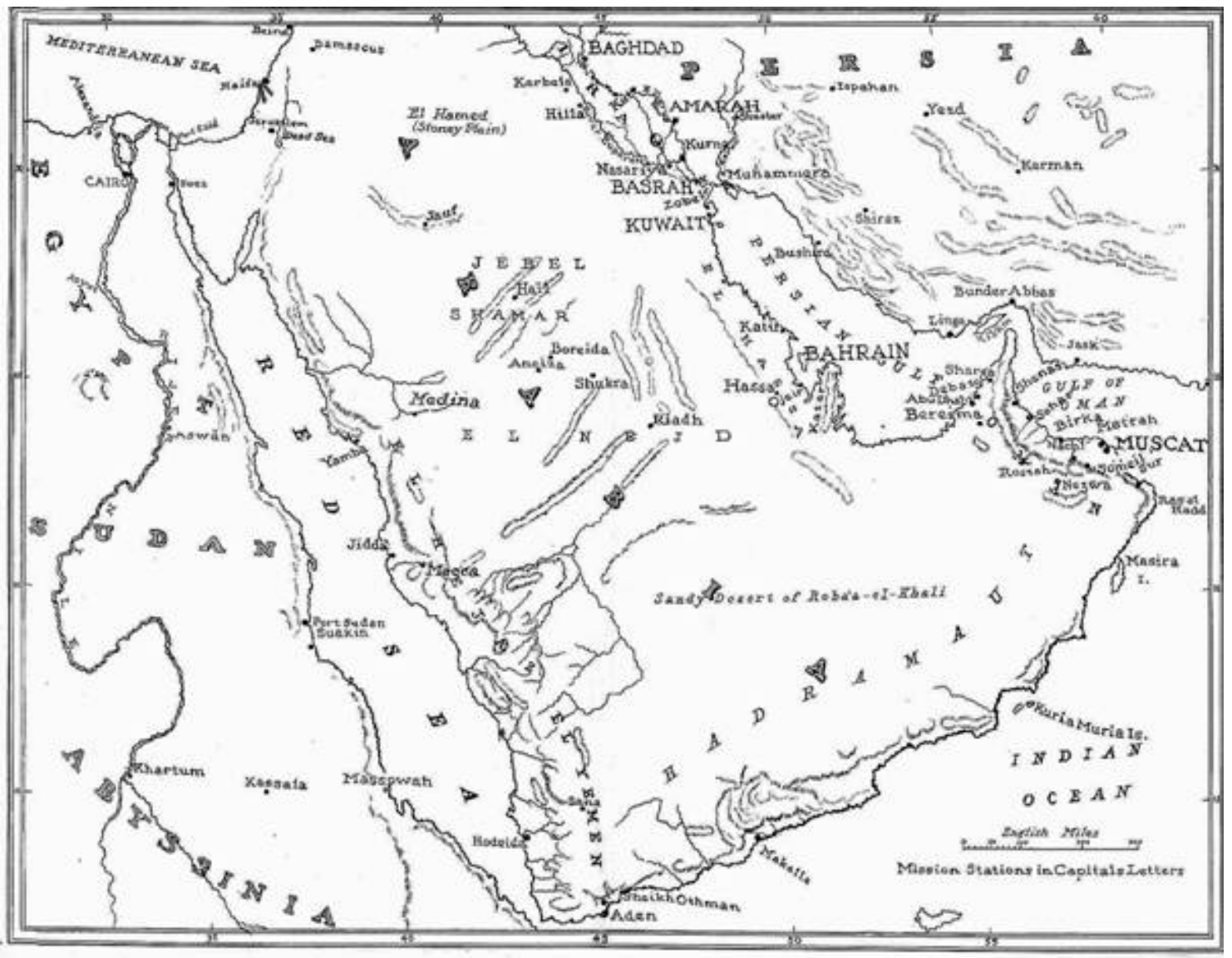


Resim 1 Arabistan misyonunun yayılım sahasını gösteren bir harita, yıl 1926. (Kaynak: http://www.gosselink.us/dear_folks/voyage.html\#image012)

Arabistan coğrafyasının batılı kadınlar ile olan ilişkisi on dokuzuncu yüzyılın ilk yıllarından itibaren bașlamıștı. Bu coğrafyanın sahip olduğu gizem, batı dünyasında her ne kadar gezgin, entelektüel ve maceraperest erkekler arasında revaçta olsa da aynı durum benzer özelliklere sahip kadınlar arasında da mevcuttu. Bu nedenle on dokuzuncu yüzyılın başından itibaren Arabistan yarımadası Gertrude Bell, Freya Stark, Theodore Bent ve Anne Blunt gibi batılı kadınlar tarafından ziyaret edilmeye başlandı. Bu gezgin ve maceraperest kadınların yolculukları sırasında düzenli ve planlı bir şekilde Arap coğrafyası ve Araplar hakkında tuttukları hatıra notları ve günlükler, bugün Arap körfez ülkelerinin tarihine önemli bir katkı sağlamaktadırlar. On dokuzuncu yüzyılın sonlarına doğru yaklaşılınca Arabistan bölgesi farklı bir batılı kadın kesimi tarafından ziyaret edilmeye başlanır (Brouwer, 1990). Fakat bu kesim gezgin veya yazar olmayıp bölgeye kendilerinden önce gelen kadınların gidemedikleri bölgelere gidip bölgenin ana lisanı olan Arapçayı çok iyi öğrenip Arap toplumu içinde yıllarca kalarak bu toplumu istenilen yönde değiştirmek için ellerinden geleni ardına koymayan misyonerlerden başkaları değildi (Al-Sayegh, 1998: s. 341). Amerikan Protestan misyoner hareketinin kıta dıșı kolu, Arabistan yarımadasını yeni bir misyon sahası olarak belirleyerek Arap misyonunu (Arabian Mission) başlattı. Misyonun kurulmasının hemen ardından bölgeye öncü bir gurup kadın misyoner gönderilerek bölgeye daha önceden gelen erkek misyonerlerin giremediği alanlara temas etme imkânı elde edilmeye çalışıldı. Kadın misyonerlerin, evlerinden binlerce kilometre uzakta bulunan ve çoğunluğu çöllerle kaplı bu coğrafyaya görev aşkıyla gelmelerinin ardında yatan motivasyonun ne olduğunu anlamaya çalıștığımızda Hristiyan kilisesine olan hizmet aşkı ve Hz. İsa için adam kazanma isteğinin kadın misyonerlerin kalplerinde önemli bir yer işgal ettiğini iddia edebiliriz (Al-Sayegh, 1998: s. 341).

Arabistan misyonunun oluşumunda önemli bir paya sahip olan Amerika'daki Hollanda Reform Kilisesi (Dutch Reformed Church), 1889 yllında ilk bekâr erkek misyonerlerin Arabistan bölgesine ulaştırılmasında maddi katkısını sundu. Protestan misyoner örgütler arasında gerçekleşen bu iş bölümü, hepsi de aynı İlahiyat Fakültesi (Theological Seminary) mezunu olan Samuel Zwemer, James Cantine ve Philip Phelps gibi erkek misyonerlerin İslam dünyasında yeni bir misyonerlik faaliyeti başlatmak amacıyla Arabistan misyonuna gönderilmesi ile sonuçlandı. Dünyadaki Protestan coğrafyasını göz önünde bulunduran bu misyonerler özellikle Arabistan bölgesinin en fazla ihmal edilen bölge olarak nitelendirmede bulunarak Arabistan misyonunun mutlaka kurulması gerektiğini savunmaktaydılar. Arabistan'ın içini fethet (Occupy the interior of Arabia) sloganı ile yola çıan bu Protestan misyonerler, bölgede kurulacak olan misyonunun oluşum aşamalarını içeren planı hazırladıktan sonra misyonun kuruluşunu başlattılar (Zwemer, 1900). Fakat karşılaşılan ekonomik sıkıntılar bu başlangıcı tehlikeye soktu. Arabistan misyonunun kuruluşu için gerekli olan para Reform Kilisesi (Reformed Church) tarafından bir türlü ortaya konamıyordu. Örgütün Çin'de, Japonya'da ve Hindistan'da kurduğu misyonların ağır giderleri Arabistan misyonu için artı bir maddiyatın oluşturulmasında önemli bir engel teşkil etmekteydi. Umutsuzluk içinde olan fakat cesaretlerini hiç bir zaman kaybetmeyen bu genç misyoner erkekler, misyonun kuruluşuna yardım edebilecek bağımsız ve misyonerlik faaliyetleri ile ilgili bireyler aramaya başladılar. Misyonerlik faaliyetlerine yaptığı yardımlarla misyonerler arasında oldukça popüler olan Bayan Catherina Halstead'ın yapı̆̆ı beş bin dolarlık yardım 
Arabistan'daki misyon ateşini yakan ilk kıvılcım oldu (Mason, Barny, 1926: s. 80/91). Böylelikle kadın misyonerlerin oldukça etkin olacağı Arabistan misyonunu yine kadın bir bağışçıdan sağlanan maddi destekle açılması bu misyonun önemini daha farklı kılmaktaydı. Yıl 1889 olduğunda Arabistan misyonun iki kurucusu misyon sahasına doğru hareket ederek bir fizibilite çalışması yapma niyeti içindeydiler.

Misyon sahasına gelir gelmez çevreyi araştıran ve meydana getirilecek olan misyon kurumları için uygun merkezlerin tespit işini üstlenen bu iki erkek misyonerin, görev sahalarında ilk tespit ettikleri unsur halkın sağlık hizmetlerine olan muazzam ihtiyacıydı. $\mathrm{Bu}$ nedenle Amerika'daki misyon merkezi ile iletişimde kalarak destekçilerinden bölgeye mutlaka doktor ve hasta bakıcı gönderilmesi gerektiğini bildirmekteydiler. Bu dönemde özellikle Arabistan misyonunda bir takım nedenlerden dolayı bayan misyonerlere ihtiyacın olmadığını belirten erkek misyonerler, doktor ve hasta bakıcıların mutlaka erkek ve bekâr olmasını kadın misyonerlerin başvuru yapmasına ihtiyaç olmadığının da merkezle olan iletişimlerinde vurgulamaktaydılar (Al-Sayegh, 1998: s. 342). Misyon sahası olarak belirlenen bölgede incelemelerini sürdüren bu iki erkek misyoner, sahanın kadın misyonerler için uygun olmadığına kanaat getirmişlerdi. Bölgedeki sıcaklık ve nemin yüksek olması ve buna ilaveten geleneklerden dolayı bayanların mutlaka kapanmak zorunda olması misyon sahasını kadın misyonerler için oldukça zorlu hale getirdiği her defasında dile getirmekteydiler. Buna mukabil zaten örgütün de yeni kabul edilen Arabistan misyonuna kadın misyoner gönderme külfetine katlanacak imkânı da bulunmamaktaydı. Kadın misyonerlerin sahaya inmesini engelleyen bu nedenler ne yazık ki geçici idi. Bölgeye gelen erkek misyonerler kısa zaman içerisinde kadın misyonerlerin neler başarabileceğini görmeye başladılar. Çünkü erkek misyonerlerin bayanlar ile konuşması onlara vaaz etmesi ve daha da ötesi Arap ailesi ile iletişim kurması nerdeyse mümkün değildi. Arabistan'daki sosyal yapının temel taşlarını her geçen gün daha iyi anlamaya başlayan erkek misyonerler, kadının bu toplum içerisindeki rolünü görerek özellikle de Arabistan misyonunda kadın misyonerlerin daha fazla başarılı olabileceğini düşündükleri andan itibaren Arabistan misyonunun şekillenmesinde kadın misyonerlerin ağırlığı her geçen gün artmaya başlayacaktı.

Arabistan misyonu, başlangıcından sonuna kadar geçen süreçte yapılan misyonerlik faaliyetleri her biri kendine has özellikler ve uygulamalar taşıyan üç önemli bölüme ayrılabilir. İlk bölüm diye adlandırabileceğimiz 1896 ve 1914 yılları arasında gerçekleştirilen misyon faaliyetlerinde kadın misyonerlerin misyon sahasına çoğunlukla misyoner eşi olarak intikal ettiklerini ve yine bu dönemde kadın misyonerlerin direkt sahaya çıkıp propaganda faaliyetlerine başlamaktansa çevreye uyum için gerekli olan zamanı kazanmak amacıyla genellikle evdeki işleri ile meşgul olma ve eşlerine yardım etme çalışması içinde olduklarını görmekteyiz. Arabistan misyonunun bu ilk döneminde kadın misyonerler, direkt olarak okul gibi misyon kurumları oluşturmaktan kaçınarak daha çok sahada yaşayan kadınlar arasında bir yer edinme mücadelesi içinde olmayı tercih ederek bölgedeki kadın toplumu içerisine sızarak iletişim kurup onlara giyimiyle ve davranışıyla batılı bir bayan portresi sunmayı hedeflediler. Bu hedeflerine ulaşmak için de kadın komşuları ile devamlı bir araya gelerek yapılan sohbetlerde Hristiyan bir yaşam tarzının nasıl olduğunu ve bu dinin değerlerinin nelerden oluştuğuna iyi örnekler vermeye çalışarak bir özendirme propagandası içine girdiler. Misyonun ikinci bölümü 1914 ile 1936 yılları arasında geçen zaman diliminden meydana gelmektedir. Birinci dünya savaşı sırasında her ne kadar misyonerlik faaliyetleri gerçekleşmemiş olsa da bu dönem zarfında Arabistan misyonunda görevli misyonerler 
hedeflerini gerçekleştirmek için önceden belirledikleri stratejilerini hayata geçirmeye çalıştılar. Misyonun devamı ve daha da işlerlik kazanması açısından bölgeye bekâr kadın misyonerler gönderilmeye başlandı. Misyon sahasına gelen bekâr kadın misyonerler, eğitim ve sağlık alanlarında istihdam edildiler. Kendilerine olan güvenleri, mesleki yeterlilikleri ve Protestanlığa adam kazandırma aşkı ile misyon sahalarında eğiterek, iyileștirerek ve vaaz ederek yerel kadınlar arasında Protestanlığı yaymaya çalıştılar (Vander Werff, 1977: s. 67/69). Arabistan misyonunun üçüncü bölümüne baktığımızda bu dönemin 1940’lı yıllardan itibaren başladığını ve misyonun kaldırıldığı yıllar olan 1970'li yıllara kadar uzandığını görmekteyiz. Bu dönemde Arabistan misyonuna kadın misyoner gönderimi devam etmekle birlikte bölgele gönderilen kadın misyonerlerin öncekilerine oranla daha fazla entelektüel ve donanımlı olmasına özen gösterildiğini fakat kadın misyonerlerin sayısında da bir düşüş yaşandığını söyleyebiliriz. Yine bu dönemde de süregelen Protestanlığa adam kazandırma mücadelesi başarılı olmamasına rağmen Arabistan misyonunun son döneminde sahaya gelen donanımlı kadın misyonerlerin bölgedeki eğitim ve kültürel faaliyetlere dokunuşları inkâr edilemez bir sosyal değişimin ateşleyicisi olarak karşımıza çıkmaktadırlar. Misyon sahaları içerisinde kız çocuklarının eğitimine önem verilmesinden dolayı misyonerlerce açılan başta yüksekokullar olmak üzere çeşitli seviyelerdeki kız okullarında verilen eğitim müfredatında yer alan eşitlik, liberalizm, sosyal statü ve bayan istihdamı gibi kavramlar Arabistan körfezini içeren coğrafyada yaşayan kadınların düșünce tarzlarında değişikliğe neden olarak içinde bulundukları zorlukları sorgulamaya başlamalarını sağlamıştı (Tuson, 2003; Van Den Berg, 2005: s. 108/109). Yukarıda özetlemesini yaptığımız bu üç dönemin daha iyi bir şekilde anlaşılması için çalışmamızın sonraki bölümlerinde bu dönemleri ayrıntılı bir şekilde incelemeye çalışacă̆ı.

\section{Kadın misyoner eşlerinin Arabistan misyonuna katılımı}

Yirminci yüzyılın ilk yıllarına gelindiğinde özellikle Amerikan toplumlarında kadınların kiliseye hizmet etmeleri ve Protestanlığın tüm dünyaya yayılmasında kadınların da aktif rol üstlenmesi yönünde kadınlar arasında cesaret artırıcı faaliyetlerde bulunan tek kurum kiliselerdi. On dokuzuncu yüzyılın başından itibaren Ortadoğu topraklarına giren Protestan misyonerler Osmanlı coğrafyası içerisinde bulunan Bilad-ı Şam bölgesinde Müslümanlar, Yahudiler ve Doğu Hristiyan toplumları arasında misyonerlik hareketini başlattıktan sonra kadın misyonerlere olan ihtiyaç her geçen gün artmış ve sonuç olarak bölgeye gelen başta misyoner eşleri olmak üzere diğer bekâr kadın misyonerler, misyonun kısa sürede ivme kaydetmesine katkı yaparak özellikle erkek misyonerlerin iletişim kurmakta başarısız olduğu alanlarda misyonun başarı kazanmasına neden olmuştu (Ümit, 2014: s. 20). Böyle bir tecrübeye sahip olan Amerikan Protestan kiliseleri ve bu kiliselere bağlı olan misyoner örgütler kadının bir eş olarak üstlendiği görevinin yanında misyon tarafından yüklenecek görevleri de yerine getirme kabiliyetine sahip olduğu görülmeye başlandı. Bu nedenle sadece kadınlardan oluşan misyoner hareketler ve bu hareketleri destekleyecek yine kadın oluşumundan mütevellit Protestan misyoner örgütler kurulmaya çalışıldı. On dokuzuncu yüzyıldan yirminci yüzyıla girerken özellikle Amerikan misyonerlik faaliyetleri kadın misyonerlerin merkezde olduğu ve önemli görevlerle donatıldığı bir yapılanma içerisine girmişti. Kadınlar arasında kilise için çalışma düşüncesi kendisini dini işlere adama kararı ile eşdeğer bir sonuç doğurduğu kabul edilmekle birlikte standart bir misyoner eşi olup sıradan ev işleri ile uğraşmaktansa sadece din için mücadele eden ve normal ev işlerini de bu amaçtan ayırarak önemsiz gibi gören bir misyoner eşi olma tercihi, bu dönemde kilise ile çalışmaya başlayan kadınlar arasında oldukça 
revaçtaydı (Al-Sayegh, 1998: s. 340).

ORGANIZED 1889. UNDENOMINATIONAL.

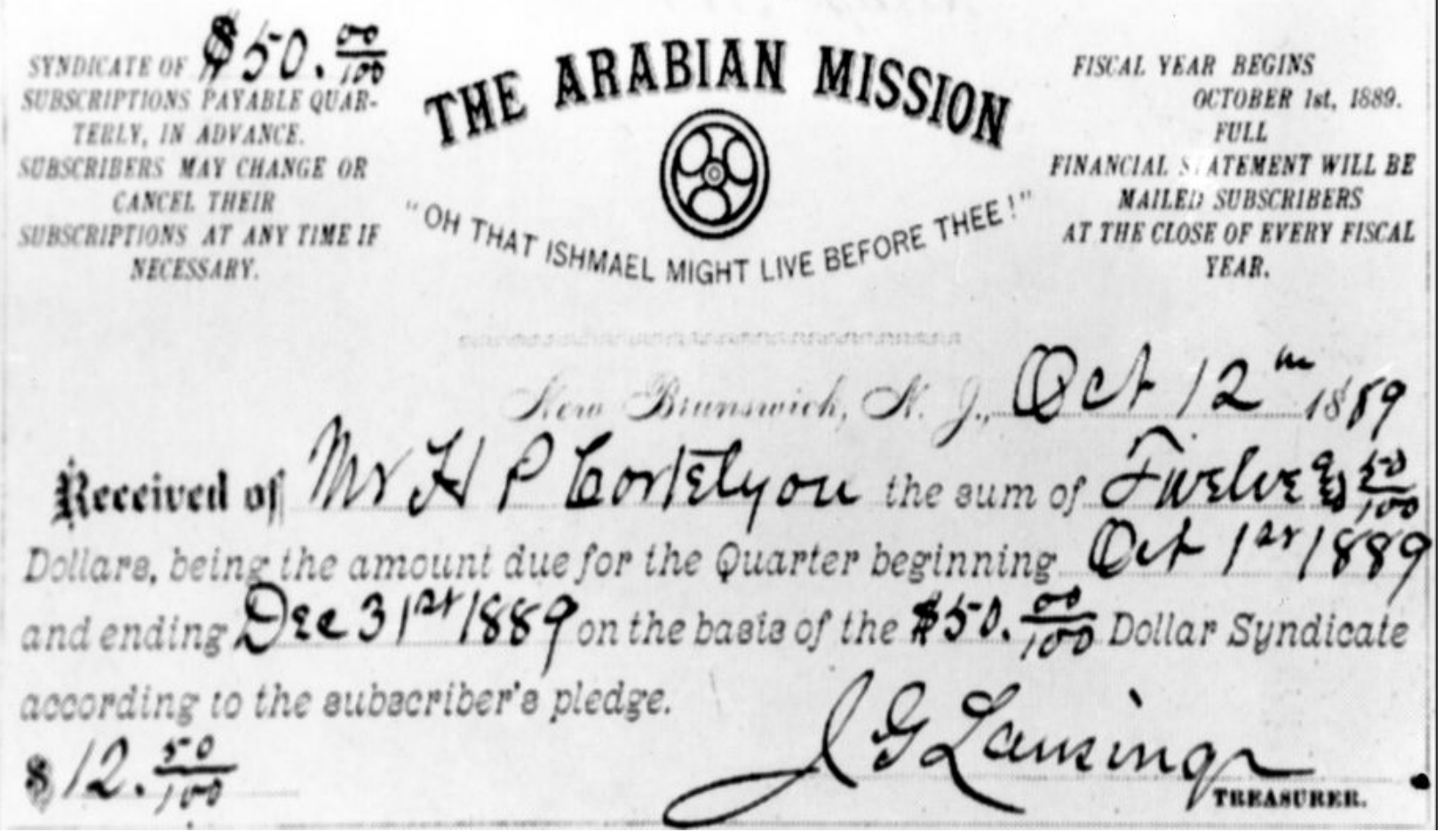

Resim 2 Bahreyn'de açılan Amerikan Hastanesi'nde görev üstlenecek misyonerlerin misyon sahasına gönderilmesi için toplanan bağışlara kesilen 12 Ekim 1889 tarihli bağış makbuzu. (Kaynak: http://www.amh.org.bh/history/)

Arabistan misyonunda da dünyanın diğer bölgelerinde kurulmuş olan Protestan gibi kadın misyonerlere olan ihtiyacın belirmesi, Arabistan misyonunu organize eden örgütün bölgeye daha önceden gönderdiği erkek misyonerlerin eşlerini de gönderme kararı alması misyon sahasına ilk kadın misyoner akışını başlattı. Bu kadın misyonerler de eşlerinin dini görevlerini benimsemiş onların sahip olduğu Büyük Uyanış doktrinini paylaşmalarına rağmen iyi eğitimli olmayıp misyon sahasının gerektirdiği zorluklara göğüs gerecek yeterli bilgi ile donatılmamışlardı. Arabistan misyonunun bu ilk dönemlerinde kadın misyonerler vakitlerinin önemli bir bölümünü, kendi içyapısında basit ve nerdeyse sınıfsız bir toplumu teşkil eden Arap sosyal yapısını inceleyerek geçirdiler. Arap toplum yaşamında din faktörünün azımsanamayacak derecede önemli bir yer edindiğini ve bütün toplumsal kurallarda bu faktörün şekillendirici bir rolü olduğuna kanaat getiren Protestan misyonerler, özellikle bu dönemde Arapların dinlerini değiştirmek için direkt hareketlerde bulunmak misyonerler için çok tehlikeli durumlar yaratacağından dolayı daha farklı stratejiler izlemek zorunda kaldılar. Bu gözlem doğrultusunda Protestan misyonerler, uyguladıkları geleneksel din değiştirme metotlarında değişikliğe giderek din değiştirme propagandası yerine ilk önce misyon sahalarında bulunan halkların güvenini ve sempatisini kazanarak halk tarafından benimsenmenin faaliyeti içine girdiler. Arabistan misyonunda görevli olan kadın misyonerlerin düzenli ve devamlı bir şekilde gerçekleştirdikleri ev ziyaretleri, bu ziyaretler sırasında sundukları sağlık hizmetleri ve ilaç yardımı, ayrıca yerel ev kadınlarına ev işlerinde 
kendilerine kolaylık sağlayacak pratik mesleki eğitimlerin yine bu ziyaretlerde sunulmaya çalışılması misyonerlere olan güvenin artmasına oldukça yardımcı oldu. Arap toplumunun kutsallarına dokunmadan kendilerine sunulan bu hizmetler ile halkın güvenini kazanmayı hedefleyen misyonerler, Arap toplumunun İslamiyet'ten Protestanlığa geçişinin kendiliğinden gerçekleşebileceği bir zemini hazırlamayı ummaktaydılar.

Arabistan toplumsal yapısının çok eski kökleşmiş geleneklerden oluştuğunu gören kadın misyonerler, çok eşlilik, çocuk evlilikleri, cariyelik ve kolay boşanma gibi çoğunluğu erkeklerin lehine oluşmuş bu yapının kadınlar için çok zor bir ortamın gelişmesine sebebiyet verdiğini bir fırsat olarak görerek kadınların durumunu iyileştirmek için atacakları her adımın bu topluluğu Protestanlığa kazandırmak için atılacak her adım ile eşdeğer görmekteydiler. Bu nedenle kadın misyonerler Arap sosyal yapısının temelinde bulunan kadını kendilerine hedef olarak belirleyerek propagandalarını bu hedefe yönlendirdiler.

Arabistan misyonunda görev alan öncü olarak kabul ettiğimiz ilk kadın misyoner eşlerinden biri olan Amy Zwemer, her ne kadar misyona Amerika'dan dâhil olsa da bir Amerikalı olmayıp İngiltere'de doğmuş bir misyonerdi. 1896 yılında misyona dâhil olup görev alan Amy Zwemer, Arabistan coğrafyasına gönderilen ilk bayan misyonerdi. Genç kızlık dönemlerinde iyi bir hemşirelik eğitimi alan Amy Zwemer, Arabistan misyonuna katılmadan önce bu mesleğini icra etmekteydi. Arabistan misyonunun kurucuları arasında yer alan Samuel Zwemer ile evlenen Amy Zwemer, bu evliliği sonrasında misyonerlik faaliyetlerinde aktif görev üstlenerek misyon sahasındaki Arapların evlerini ziyaret etmeye başlamıştı. $\mathrm{Bu}$ ziyaretleri sırasında sağlık hizmeti ihtiyacı içinde olan Arapları tedavi etmek amacıyla evleri dolaşan erkek misyonerlere de yardımcılık görevinde bulunarak özellikle bayanların bu hizmetten olabildiğince yararlanmasını sağlamaya çalışmaktaydı. Arap misyonunda görevli erkek misyonerlerin bölgede rahat dolaşmasını ve özellikle de bayanların yoğun olduğu alanlara girmesinin önünü açması nedeniyle misyonda Amy Zwemer gibi tıp alanında yetenekli bir kadın misyonerin bulunması misyon açısından oldukça önemliydi. Diğer taraftan Amy Zwemer, Arabistan misyonuna sonradan gelen diğer kadın misyonerler tarafından da örnek olarak gösterilen bir kişilik idi (Al-Sayegh, 1998: s. 342/343). Arabistan coğrafyasına karşı gösterdiği uyum mücadelesi ve misyonerlik görevini ilk olarak yerine getirdiği Bahreyn'deki Arap kadınları üzerinde oluşturmayı başardığı etkisi, ondan devamlı söz edilmesini sağlamıștı. Bahreyn'deki görevinden önce bile ilk olarak bulunduğu Basra bölgesinde, yerel kadınlar ile iletişim kurmayı başaran Amy Zwemer, ev ziyaretlerine Basra'da bulunduğu günlerde zaten başlamıştı. Basra'daki misyon dispanserinde görevli olan misyoner Doktor H. Worrall, kendisine yardımcı olan, kadın hastalar ile iletişim kurmasını sağlayan ve bunu gerçekten samimiyet ile yapan böyle bir kadın misyonerin merkezden gönderildiği için çok mutluydu. Tedavi sırasında erkek doktor misyonerlere sadece ellerini göstererek tedavinin gerçekleşmesine izin vermeyen kadın hastaların doktorun yanında yardımcı bir bayanın bulunması ile iletişimsizliğin oluşmasını engelleyerek hastaların yüzlerini bu bayan misyoner sayesinde kontrol edebildiğini belirten Doktor H. Worrall, misyona mutlaka tıp alanında tecrübesi olan kadın misyonerlerin katılmasının önemine dikkat çekmekteydi (AlSayegh, 1998: s. 343). Amy Zwemer'in misyona katılması ile misyonda görevli diğer erkek misyonerlerin hareket alanlarının ne kadar genişlediğini fark eden H. Worrall, peçeli Arap kadınlarının da misyona tedavi için tereddütsüz gelmeye başladıklarını ve devamlı olarak kendilerine yardımcı olabilecek bir bayanın misyon hastanesinde hazır beklediğini bilmeleri, bu gelişlerin gün geçtikçe arttığını gözlemlediğinin altını çizmekteydi (Windsor, 2002). 


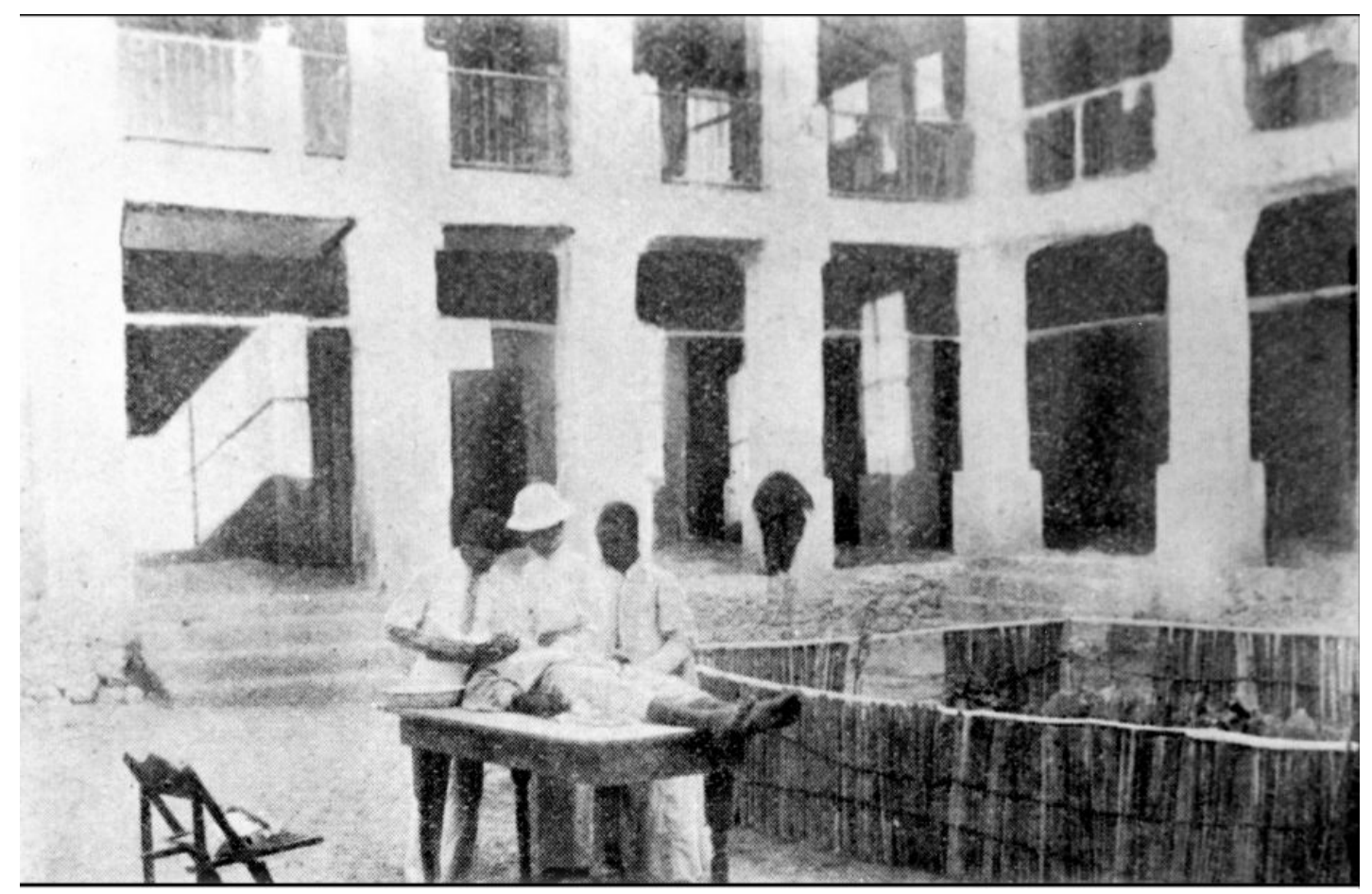

Resim 3 Misyon hastanesinde misyoner doktor tarafından yapılan bir tıbbi müdahale (Kaynak: http://www.amh.org.bh/history/)

Amy Zwemer'in Bahreyn'deki görevinin ilk ayları, ev ziyaretleri ve doktor misyonerler ile gerçekleștirdiği hasta ziyaretlerinden dolayı oldukça yoğun geçti. Kısa sürede ortama uyum sağlaması ve bașarılı olmasının yanında erkek misyonerlerin merkeze gönderdikleri raporlarında kendisinden takdirle bahsedilmesi Amy Zwemer'i Amerika'da misyona katılmak isteyen diğer kadın misyonerler için bir ilham kaynağına dönüştürdü. Amy Zwemer, Arabistan coğrafyasının tüm zorluklarına rağmen bir kadın misyonerin bu bölgede başarılı olabileceğinin örneğini vermekteydi. Arabistan misyonunun başlangıcında misyonerlik faaliyetleri için şartlar oldukça ağırdı. Misyon sahasında hastane olmamasına rağmen tedaviye ihtiyaç duyan hastaların sayısı bir hayli fazlaydı. Bu nedenle Amy Zwemer'in sahadaki görevi şekillenerek hem sağlık alanında hizmet vermeyi gerektirmekteydi hem de bu hizmeti sunarken dini görevini de yerine getirmeyi zorunlu kılmaktaydı. Aynı durum misyondaki erkek misyonerler için de geçerliydi. Amy Zwemer'in eşi Samuel Zwemer her ne zaman İncil'den risaleler okumak için Arap erkeklerin bir arada olduğu yerleri ziyaret etmeye gittiği zaman Amy Zwemer da bayanlar arasında bulunup dua okuma ve sohbet yapmak için eline geçirdiği her fırsatı değerlendirmeye çalışarak Protestanlığı yaymanın yollarını aramaktaydı. Arap kadınlarının İncil'e ve kendisine olan ilgilerinin gün geçtikçe arttığını vurgulayan Amy Zwemer, gerçekleştirdiği sohbetler esnasında elde ettiği izlenimi yorumlayarak misyonun başarılı olacağından şüphesiz olduğunu belirtmekteydi (Al-Sayegh, 1998: s. 344). Protestan Arap misyonunun diğer önemli bir sahası olan Umman'daki Muskat şehrine görevinin ilk yılının Ağustos ayında kısa bir ziyaret yapan Amy Zwemer, bu sahada Peter Zwemer'in kurtarılmış köleler için açmış olduğu okulda kısa bir çalışmadan sonra tekrar Bahreyn'deki görevine dönerek propaganda faaliyetleri dâhilinde olan hemşirelik ve misyonerlik görevine devam etti (Zwemer, 1900). 
Bazı istisnalar dışında bu dönemde Arap misyonunda görev alan kadın misyonerler genellikle evli olup misyon sahasında eşleri ile birlikte faaliyetlerini yürütmekteydiler. Amy Zwemer ile eşi Samuel Zwemer'in misyonerlik faaliyetleri yoğunluk kazanmasından ve misyonun gelecek vadetmesinden dolayı örgüt, misyona takviye amacıyla yine tıp alanında uzman bir çift gönderdi. Marion Wells Thoms ve doktor olan eşi Sharon J. Thoms, misyon sahasına ulaştıktan sonra Zwemer ailesinin yaşadığı evde konaklamaya başladılar. Amy Zwemer, Bahreyn'de kendisine ve eşine yardımcı olarak gelen bu çifti hoş karşılayarak tecrübelerini kısa sürede onlara da aktarmaya çalıştılar. Bu dönemde Bahreyn'de düzenli bir hastane bulunmamaktaydı. Amy Zwemer ve arkadaşı, erkek misyonerler tarafından inşa edilmiş küçük bir dispanserde çalışarak özellikle yerel kadınlara ve çocuklara sağlık hizmeti sunmaya çalışmaktaydılar. Boş zamanlarında da misyon sahasının çevresinde bulunan yerleşim yerlerini ziyaret ederek toplanan kalabalığa hem İncil okumaktaydılar hem de ihtiyacı olanları tedavi etmeye çalışarak yerel kadın nüfusu ile kalıcı bir iletişim kurmayı hedeflemekteydiler. Fakat misyonerler tarafından yapılan bu yoğun propaganda faaliyetlerine rağmen henüz Protestanlı̆̆ı seçmiş bir Arap’ı rapor edememişlerdi (Al-Sayegh, 1998: s. 343).

Misyonerlik faaliyetlerinin giderek önem kazandığı on dokuzuncu yüzyılın son çeyreğinde, Ortadoğu'ya hâkim olma bu bölgede nüfuz sahaları meydana getirme isteği Rusya dâhil birçok Avrupalı devletler ile Amerika'nın alan kapma mücadelesi, misyonerlere verilen önemi daha da artırdı. Yirminci yüzyıla girerken özellikle Amerika kökenli Protestan misyoner örgütlerin yapılanmasında ve bu örgütlere üye kadın misyonerlerin sayısında önemli değişiklikler yaşandı. Protestanlığı yayma fikri ile donatılmış erkek misyonerlerin misyon sahalarında kendilerine yardımcı olmak ve özellikle de İslam dininin yaygın olduğu coğrafyada Müslüman ailelere nüfuz etmek amacıyla örgüt merkezinden kadın misyoner talebinin yanında Amerika'da kadın misyoner yetiștiren ilahiyat okullarından mezun olanlarında misyon sahasına gönderilme isteği misyoner örgütlerin evlilik kurumu çerçevesinde bu misyonerleri birleștirme yapılanmasına itti (Akgün, 2014: s. 81). Bu yeni akım sayesinde sahadaki erkek misyonerleri yalnızlıktan kurtararak işlerine daha fazla konsantre olmalarını sağlarken kadın misyonerlere de aile kurma ve Protestanlığı yayma imkânı tanıyıp örgüte de yayılım sahasını genişletme fırsatı doğurmaktaydı. Basra misyonunda görevli doktor olan Worall bu akım sürecinde kendisi ile aynı mesleği paylaşan Bayan Emma Hodge ile evlenerek Arabistan misyonunda görevli üçüncü çift oldular. Kadın Doktor Emma Hodge ile diğer kadın Doktor Marion Thoms, Arabistan misyonundaki çalışmaları ile misyon sahasına sonradan gönderilecek olan evli doktor çiftler için önemli örnek teşkil ettiler. Arabistan misyonunda yerel halka ulaşmak, onları etkilemek ve Arap ailesine sızmak için misyonerler tarafından kullanılan en önemli araç tıbbi yardım idi. Bu nedenle Arap coğrafyasında doktor olmak yada tıp alanında bilgi birikimine sahip olarak tedavi uygulamak misyon sahasına gönderilecek olan kadın ve erkek misyonerlerde aranılan önemli bir özellikti. Sağlık hizmeti, Arabistan misyonunda her kapıyı açtığı gibi misyonerlerin insanlar ile ilişki kurmasını sağlayarak kendilerine yerel halk tarafından duyulan güvensizliği ve korkuyu azaltmanın en önemli yoluydu. Müslüman denizinde Protestan propagandası yapmanın, insanlara İncil okumanın ve onları bu dini seçmeleri yönünde ikna etmenin ne kadar zor olduğunu bilen misyonerlerin bu önyargısı, sundukları sağlık hizmetinin kendilerini Müslümanlar arasında ne kadar kolay bir şekilde yer edinmelerini sağladığını görünce, yıkıldı. 
Protestanlığı yayma aşkına sahip kadın misyonerlerin Arabistan misyonuna dâhil olması yirminci yüzyılın ilk yıllarında da devam etti. 1902 yılında başka bir misyoner çift Arabistan misyonuna katılmak için Bahreyn'e intikal etti. Rahip Fred Barny ve hemşire eşi Bayan Esther Barny, Bahreyn'e gelmeden önce Basra'da belli bir süre çalıșmışlardı. Bahreyn misyon sahasında görevli olan diğer hemșire Bayan Amy Zwemer ile birlikte bir ikili oluşturan hemşire Bayan Esther Barny, misyon sahasındaki yerleșim yerlerine düzenli ziyaretlerde bulunarak hasta olanlara tedavi uygulamaya çalışırken bir yandan da toplanan kalabalığa İncil'den pasajlar okumaya çalışmaktaydılar. Bu süreçte de ne yazık ki Protestanlığa kazandırdıkları bir kişi bile yoktu.

Arabistan misyonunda Amerika'dan gönderilen Protestan kadın misyoner sayısı giderek artmasına rağmen misyon sahasına gelen kadın misyonerlerin nerdeyse hiç biri Arabistan misyonu kuran Amerikan Hollanda Reform Kilisesi (Dutch Reformed Church)'nin bir üyesi olmayıp Protestanlığın farklı mezheplerine bağlıydılar. Protestanlığın farklı mezheplerinden kadın misyonerlerin Arabistan misyonundagörevlendirilmesindeönemli rol oynayan Hollanda Reform Kilisesi, gönüllü kadın misyonerleri sahaya göndererek bölgeye sonradan gönderilecek olan bekâr bayan misyonerler için imrendirici bir zeminin hazırlanmasına çalıştı. Böylelikle 1902 yılında Hollanda Reform Kilisesi üyesi olan Bayan Elizabeth De Pree, Protestanlı̆̆ın bu mezhebini ve kiliseyi temsilen misyon sahasına gönderilen ilk bekâr bayan misyoner oldu. Hemşirelik eğitimi alan Bayan Pree, dil eğitimi almak için ilk önce misyonun Bahreyn'deki istasyonuna ulaştırıldı. Bahreyn'de görevli misyoner çift olan Bay ve Bayan Thoms'un izin alarak bölgeden ayrılması ile boşalan hemşirelik pozisyonunu dolduran misyoner Bayan Pree, Bayan Zwemer ile birlikte çalışarak Bahreyn'deki yerel bayanlar arasında sağlık hizmeti sunma şemsiyesi altında Protestan propagandası yapma mücadelesini sürdürdüler. 1904 yılında Bhareyn'de görevli ve Arabistan misyonunun kurulmasında rol üstelenmiş olan misyoner rahip James Cantine ile hayatını birleștiren Bayan Pree, görevini hemşire olarak sürdürdü. Bu misyoner çift, Bahreyn'de yirmi yıldan fazla bir süre kalarak öğretmenlik ve hemşirelik mesleklerini icra ederek bölge halkına Protestanlığı tanıtmaya çalıştılar. Bu sırada misyona gönderilen bekâr bayan misyonerlerin sayısında artış yaşanmaktaydı.1904 yılında Bahreyn'e gelen bir diğer misyoner ise Bayan Fannie Lutton idi. Arap çocukları ve kadınları arasında Protestanlık propagandası yapma amacıyla bölgeye gelen Bayan Lutton, Basra, Bahreyn ve Muskat'ta görev üstlenerek misyonda izinli olan misyonerlerin sorumlulukları altında bulunan ziyaretleri gerçekleştirmekteydi. Bu yıllarda Arabistan misyonuna katılan bir diğer bekar bayan misyoner Bayan Patterson idi. Doktor olan Bayan Patterson, izinde olan Thoms çiftinin görev sahasının sorumluluğunu üstlenerek bölgede sağlık hizmeti içinde olan aileleri dokuz ay boyunca ziyaret etti.

Arap misyonunun önemli istasyonlarından biri olan Bahreyn, misyonun kadın misyonerlerine ev sahipliği yapan tek istasyon olmamasına rağmen yine de Protestan kadın misyonerler arasında önemli bir yeri vardı. Arap misyonunda görev üstlenen kadın misyonerler arasında her zaman Arap yarımadasının Protestanlık tarafından işgal edilmesi hayali dile getirilmekteydi. Bu hayalin bir gün gerçekleşeceğini belirten bölgeye ilk gelen kadın misyonerler, sonraki misyonerlerde de bu umudun yeşermesi için konuyu devamlı gündemde tutmak bu tecrübeli misyonerlerin görevleri arasındaydı (Storm, 1938: s. 65/67). Bu dönemde misyonda görevli olan bayan ve erkek misyonerler, görevlerini belirli bir binada yerine 
getirmektense halk arasında gezinip ziyaretlerde bulunarak ücretsiz sağlık hizmeti sunmaya çalışarak propagandalarını bu sunum içeriğinde yapmaktaydılar. Misyonun çevresindeki köyleri de ihmal etmeyerek arta kalan zamanlarda da bu yerleşim yerlerini dolaşmaktaydılar. Ev ziyaretleri ve hasta ziyaretleri bu dönemde misyonun hem gelişmesinde hem de İncil'in tanıtılmasında önemli bir yöntemdi. 1904 yılına gelindiğinde Arabistan misyonunun farklı alanlarında da misyonerler etkinliklerini artırmaya çalışmaktaydılar. Bu yıl içerisinde Bahreyn misyonunda görevli Cantine çifti, Arabistan misyonunun en zor sahalarından biri olan Muskat istasyonuna hareket ettiler. Bayan Cantine, Muskat'a gelir gelmez kız çocukları için bir dikiş okulu açarak kız çocuklarının aileleri ile iletişim kurmayı hedefledi ve diğer taraftan bir dispanser oluşturarak özellikle aileleri ziyaret edip hasta olanları tedavi etmeye çalıştı. Eşiyle birlikte devamlı hareket halinde olan Bayan Cantine ziyaretlerini sonraki dönemlerde Umman'ın içine yöneltmeye başladı. Bahreyn'den beraberlerinde getirdikleri matbaa malzemeleri ile küçük bir baskı atölyesi de oluşturan Bay Cantine misyonun yazınsal materyal ihtiyacını da kendisi karşılamaktaydı. Protestan misyoner Bayan Cantine, Umman'da yaptığı çalışmalar ile Arabistan misyonunun bu bölgeyi de kapsamasına olanak tanıyarak Umman'na gelen ilk kadın misyoner olarak nitelendirildi. Bu bölgedeki faaliyetleri ile kendisinden sonra bölgeye gelecek olan kadın misyonerlerin önünü açan Bayan Cantine bu özelliğiyle de kadın misyonerler arasında oldukça önemli bir yere sahipti (Al-Sayegh, 1998: s. 344/345).

Arabistan misyonuna kadın misyonerlerin dâhil olması ve bu misyon sahası özellikle de bekar bayan misyonerler arasında oldukça popüler olmaya başlaması bu misyon sahasının kısa sürede genişlemesini sağlayarak yeni istasyonların kurulmasını ve yeni katılımların önünü açtı. Denilebilinirki Arabistan misyonunun ilk on yılı misyonerlerin bölgeye yerleşmesi ve alışması süreci sonraki on yıl ise bölgeye gelen misyonerlerin asıl amaçlarını icra etmeye başlayarak misyonun gelecek vaat etmesinde önemli görevlerin üstlenildiği yıllar olarak değerlendirebiliriz(Storm, 1938:s. 66/67).1905-6yıllarında Arabistan misyonuna gönderilen yeni misyonerlerin sahaya inmeleri ile misyona Katar ve Kuveyt gibi iki yeni istasyon daha eklenerek bu istasyonlara da misyoner akışı başladı. Bayan Zwemer'in Arabistan misyonuna katılmasından on yıl sonra misyona katılan kadın misyonerlerin sayısı ona ulaşmıștı.

Yirminci yüzyılın başından itibaren Amerika kökenli Protestan misyoner örgütlerin Arabistan bölgesine gösterdiği ilgi her geçen gün artarak süregeldi ve bu ilgi bölgeye gönderilen misyoner sayısının artışına da neden olmaktaydı 1912 yllına gelindiğinde Arabistan misyonunun sahip olduğu istasyon sayısı bir hayli yükselmişti. Amerikalı Protestan misyonerler, sadece Arap yarımadasının kıyı kesimindeki şehirler ile ilgilenmiyorlar aynı zamanda yarımadanın iç kesimleri ile de ilgilenmeye başlamıştılar. Arap yarımadasının tamamında Protestanlığı yaymayı hedefleyen misyonerler, toplumun sadece bir kısmıyla değil nerdeyse tümüyle ilgilenerek kısa sürede başarı elde etmek istiyorlardı. Kadın misyonerlerin özverili ve özendirici çabaları bu zorlu coğrafyaya başka misyonerlerin de gelmesine katkı sağlayarak gelen misyonerlere yeni çalışma sahalarının oluşturulması amacıyla da yarımadanın farklı alanlarında yeni misyon istasyonları kurulmaya çalışılmıştı. Kuveyt, Protestan misyonerlerce Arabistan misyonunda yeni açllan önemli istasyonlardan biriydi. Kuveyt istasyonunun açılması sonrasında bölgeye sağlık hizmetinde deneyim sahibi bir misyoner çift gönderildi. Arabistan misyonunun açılmasından on yıldan fazla bir süre sonra misyona katılan Calverley çifti Kuveyt'e gönderilen ilk Protestan misyonerlerdi. Doktor olan Bayan Eleanor Calverley ve eși olan Rahip Edwin Calverley, Kuveyt istasyonunda on sekiz yıldan fazla bir süre görev yapacaklardı. Kuveyt'teki misyon sahasında erkek 
çocukların İngilizce dilini öğrenmeleri için bir okul hazırlayan Edwin Calverley, bu eğitim hizmetini sürdürdügü sırada doktor eşi Bayan Eleanor Calverley de önceki misyon sahasında edindiği tecrübe doğrultusunda bölgedeki yerel bayanları düzenli bir şekilde ziyaret etmekte ve merkezde hazırlamış olduğu dispanser şeklindeki küçük kliniğinde hastaları tedavi etmeye çalışmaktaydı. Kuveyt'in merkezindeki bu kliniği ziyaret edenler ilk kez Hristiyan misyonerler ile karşılaşmaktaydılar. Misyoner Bayan Calverley, kendi hayat hikâyesini yazdığı otobiyografisinde (My Arabian Days and Nights) Kuveyt misyonunun stratejik olarak ne kadar önemli bir noktada olduğuna dikkat çekerek bölgenin ticari bir merkez olarak öne çıktığını ve sahibi olduğu limana Arap coğrafyasından birçok geminin yanaştığını belirtmekteydi. Bunun yanında eşiyle birlikte gerçekleștirdiği faaliyetler hakkında otobiyografisinde bilgi veren Bayan Calverley, kendisinin küçük bir klinik meydana getirerek hastaları tedavi etmeye çalıștığını bu tedavi sürecinde hastalarına Protestanlığı İncil okuyarak aşılamaya gayret ettiğini ve özellikle yerel kadınlar ile iyi geçinerek bu insanların misyonerleri birer yabancı gibi görmesinin önüne geçmeye çalıştığını vurgulamaktaydı (Calverley, 1958: s. 15). Kuveytli kadınların kendisini ilk başlarda yabancı olarak gördüğünü belirten Bayan Calverley, gelinen noktada bu kadınların İslamiyet'te de kutsal sayılan Hz. İsa'nın dinine mensup bir bayandan tedavi hizmeti görmeleri konusunda oldukça memnun olduklarının da altını çizmekteydi (Missionary Review Publishing Co, 1911).

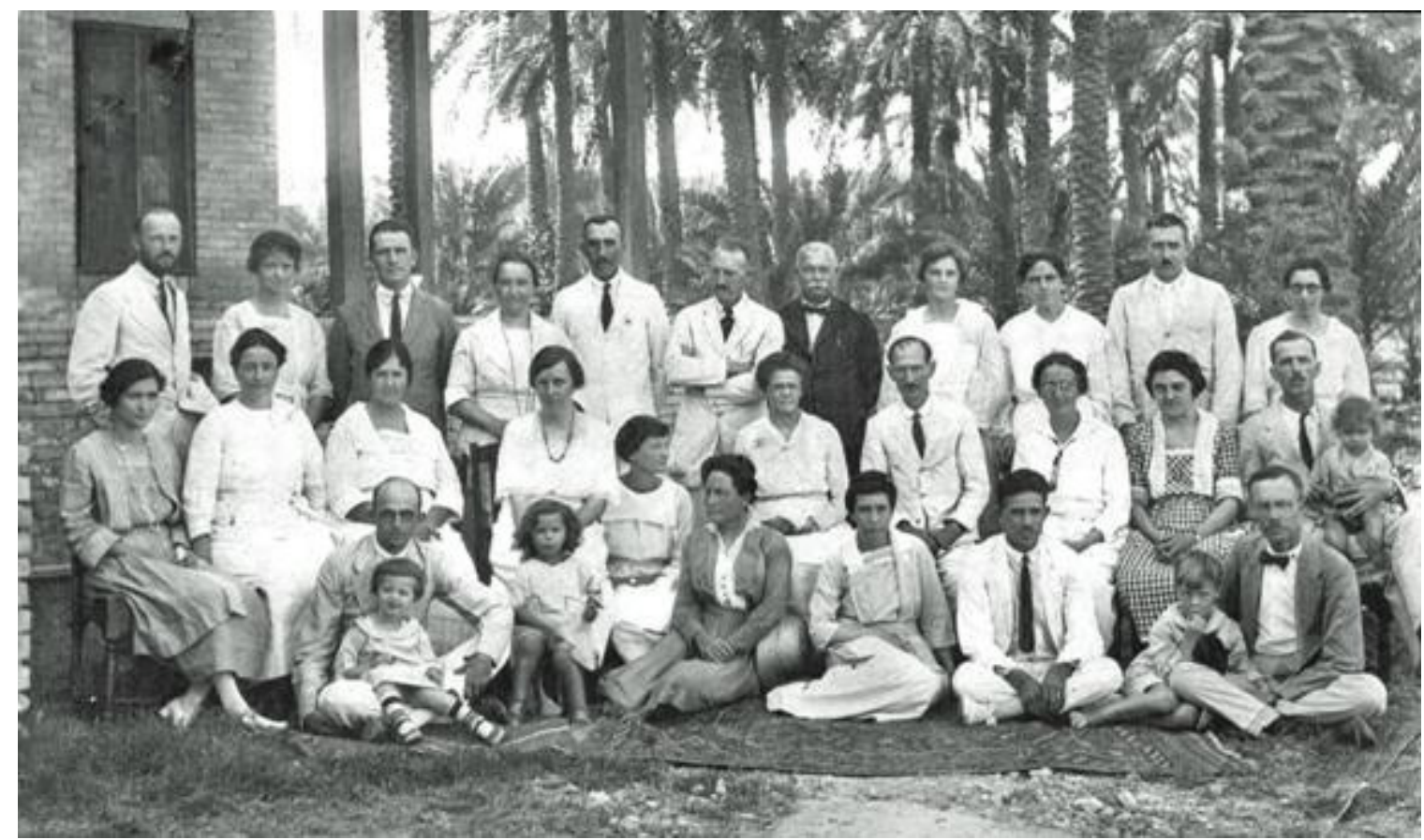

Resim 4 Arabistan misyonunun 1922 yılında Basra'daki geleneksel toplantısından bir görünüm. (Kaynak: http://www.gosselink.us/dear_folks/epilogue.htm, )

Misyon stratejisi gereği Arabistan misyonunda açllan her yeni istasyona evli misyoner çiftlerin gönderilmesi geleneği devam etmekle birlikte bu strateji Kuveyt için de uygulandı. Bölgeye gönderilen ilk evli çift olan Calverley çiftine ek olarak yine doktor ve ebeden oluşan Bay Stanley Mylrea ile Bayan Bess Mylrea çifti, 1913 yılında Kuveyt'teki görevlerine başlamıştı. Arabistan misyonundaki görevlerine 1907 yılında başlayan bu çift, Bahreyn'de beş yıl kalıp dil ve çevre hakkında önemli tecrübeler kazanarak misyonerlik faaliyetlerinde ehil bir çift 
olmuşlardı. Ayrıca Bahreyn'deki misyon hastanesinde görev üstlenerek tedavi sırasında Protestan propagandasının nasıl gerçekleştirildiği konusunda da önceki misyonerlerin tecrübesinden yararlanarak aynı stratejiyi Kuveyt misyonunda da uygulamaya koymaya çalışacaklardı. Bu nedenle doktor olan Bay Stanley Mylrea, bayan bir misyonerin yardımı olmadan misyon sahasındaki yerel kadınların tedavi edilmesinin din ve geleneklerden dolayı pek mümkün olmayacağının farkında olması onu bu engeli eşini kendi çalışma stili konusunda eğitmesi ile aşmaya itti. Tedavi sırasında uyguladığı protokolleri eşine öğreten Bay Stanley Mylrea, hastalık belirtilerinin vücudun hangi uzuvlarında ne şekilde kendini gösterdiğini ve tedavinin gerçekleşebilmesi için hastanın nasıl hareket edebileceği konusunda hastaya gerekli bilgilerin nasıl verilmesi hususunda eşini kullanmayı kararlaştırmıştı (Calverley, 1958: s. 67/68). Erkek bir doktora muayene olmaktansa daha da ötesi erkek birine onun istediği uzuvları göstermektense ölmeyi tercih eden Arap kadınlarının ortaya koyduğu bu önyargıyı azaltmak için Bay Stanley Mylrea, eşini bir doktor gibi yetiştirerek bu tür hasta ziyaretlerine eşi ile birlikte katılmaktaydılar. İzlenen bu strateji Bayan Mylrea'a da tıp alanında önemli bilgiler kazandırarak yerel halk tarafından saygı görmesini sağladı. Mylrea çiftinin kurduğu ufak çaplı hastanede ebe ve hemşire olarak görev yapan Bayan Mylrea da Kuveyt misyonunun gelişmesinde katkısı olan önemli bir kadın misyoner olarak misyonerler arasında tanınmaya başlanmıştı. Misyon hastanesi aynı zamanda misyona yeni katılan kadın misyonerlerin de adeta bir staj yapma olanağı da sunduğundan dolayı bir misyon merkezi haline dönüşmüştü. Misyona katılan diğer bir bekâr bayan misyoner ise Mery Van Pelt adındaki misyonerdi. Hemşire olarak misyon hastanesinde görev üstlenen bu misyoner, özellikle hastaneye tedavi için gelen ve hastanede belli bir süre yatmakta olan hastalara Protestanlık propagandası yapmakla birlikte kadınlar ile iletişim kurmak onlara İncil okumak amacıyla da düzenli ev ziyaretleri de gerçekleștirmekteydi.

Arabistan misyonunda şartlar Protestanlık propagandası yapmak için oldukça ağırdı. Misyon sahasına gönderilen misyonerlerin asıl görevi Protestanlı̆̆a adam kazandırmak olmasına rağmen misyonerler, dini propagandadan çok misyon sahasındaki insanların eğitim ve sağlık ihtiyaçlarına cevap vermeye çalışmaktaydılar. Haliyle bu durum misyonerlerin asıl görevlerine yoğunlaşmalarını engellemekteydi. Protestanlığı kabul edenlerin sayısında artış yaşanmamasının en önemli nedenlerden birini de misyonerlerin din dışında her şeyle uğraşması oluşturmaktaydı. Bölgede görevli kadın misyoner olan Bayan Mylrea'nin dile getirdiği şikâyetlerinin başında özellikle ev ziyaretlerinde istekli Arap kadınlarına yeteri kadar İncil okuyamama ve onları Hristiyanlık yaşam tarzı ile tanıştıramama konusuna değinerek bu durumun Arap kadınları arasında Protestanlığın yayılamamasında da etkili olduğunu vurgulamaktaydı. Arabistan misyonunda görevli misyonerler, bölgenin sahip olduğu değerler ve gelenekler din değiştirmenin önünde önemli bir etken olduğunun altını çizerek ancak insani yardım şemsiyesi altında yerel halk ile ilişki kurabildiklerini ve zamanın çoğunu bu tür yardım faaliyetlerine ayırdıklarını ve nihayetinde gün içinde din değiştirme faaliyetlerine zaman ayıramadıklarını belirtmekteydiler. Diğer taraftan misyona ilk olarak katılan misyonerlerin izlenimlerine göre de Arabistan yarımadasında eğitim faaliyetlerinin neredeyse olmadığı bu nedenle bu coğrafyadaki kadınların yüzde doksan dokuzunun ve erkek nüfusunun da yüzde doksanının eğitim ile hiç bir bağının olmadığı vurgulanmaktaydı. Hastalıkların oldukça yaygın olduğu ve özellikle Tifüs, Veba ve Trahoma gibi hastalıkların gerekli tedaviyi yapacak sağlık kuruluşlarının olmamasından dolayı oldukça can aldığını belirten misyonerler, hastalıktan öte insanların temel ve hijyen eğitiminden oldukça mahrum olduğunu, cahilliğin tüm yarımadayı etkisi altına aldığını ve bu durumun ölümleri artırdığını 
durum tespitleri arasında göstermekteydiler (Windsor, 2002).

Arabistan misyonunda görevli Protestan kadın misyonerlerin yukarıda belirttiğimiz tespitleri dışında üzerinde durdukları bir diğer husus da bölgedeki yerel kadın nüfusun, fakirlik ve diğer imkânlardan yoksun olmalarına rağmen temel hijyenden bihaber olmadıkları özellikle İslamiyet gereği temiz kalmanın gerekliliği sonucu su ile temaslarının fazla olduğudur. Ancak bir takım konularda Arap kadınlarının uyguladıkları batıl ve geleneksel yöntemler bu kadınların kısa sürede hastalanmalarına ve daha da ötesi çoğunluğu ölümle sonuçlanan hastalık süreçleri geçirmelerine neden olmaktaydı. Bu hususların başında doğum kontrolünde kullanılan kaya tuzu kullanımıydı. Çocuk yaşta doğum yapma ve gebelik dönemlerinde birçok hastalığa maruz kalan Arap kadınları, antik dönemlerden kalma doğum kontrol yöntemleri kullanarak kısa süre içerisinde gebe kalmamak ve istenmeyen gebeliklerden kaçınmak için yarımadada oldukça yaygın olan kaya tuzu yöntemini uygulamaktaydılar. Hemşire, ebe ve doktor olan kadın misyonerlerin hastaları tedavi süreçlerindeki gözlemlerine göre Arap kadınları, her ne kadar genel temizlik için tuzun yararlarının farkında olsalar da bu maddeyi gebe kalmamak ya da farkında olmadan kendini kısırlaştırmak ve gelecekteki gebe kalma ihtimalini en aza indirmek için kullanmaktaydı (Boersma, 1991: s. 92/95). Genital bölgesine yerleștirilen kaya tuzunun bir hafta veya on gün kadının bu bölgesinde kalması kadının rahmine büyük zarar verdiği gibi ileriki gebeliklerin de mümkün olmamasına yol açtığının farkında olmayan ve modern doğum kontrol yöntemlerini tanımayan Arap kadınlarının bu geleneksel ve doğal doğum kontrol yöntemini uygulamaları Arap kadınları arasında özellikle evlilik sonrası ölümlerin sıklıkla yaşanmasına neden olduğu ayrıca da bu kadınların kısa sürede de sütten kesilip çocuklarının yetersiz beslenmelerine yol açtığı kadın misyonerler tarafından dile getirilmekteydi.

“Arabistan'ın iç kısımlarında kadınların durumu daha da kötüydü. Kadın için bazen birinci veya ikinci doğum onun yaşamına mal olabilmekteydi. Kullanılan batıl doğum kontrol yöntemi kadının üreme organlarına oldukça zarar vermekteydi. Diğer taraftan Arap toplumunda kadının sırtında önemli bir yük vardı. Ev temizliği, çocukların bakımı, yemek yapımı, gıda maddelerinin eve ulaştırılması ve suyun eve ulaștırılmasından sorumlu olan Arap kadınının, bunların üstüne gebelik sürecinin de eklenmesi ile oldukça güçsüz düşmekteydi. Diğer bir olumsuz etken ise yetersiz beslenmenin özellikle gebe kadınlarda meydana getirdiği tahribattı. Arap körfezinin iç kısımlarından misyon hastanelerimize gelen bu kadınları tedavi ettiğimiz sırada karşılaştığımız en önemli sorun bu kadınların doğum kontrolü için kullandıkları geleneksel kaya tuzu yönteminin kadında meydana getirdiği sıkıntılardı. Bu sorunun tedavisinde ilerlemiş olmamız bu kadınları bilgilendirmemizde ve tedavilerinin başarılı bir şekilde gerçekleşmesine yardımcı olmaktaydı (Boersma, 1991: s. 93)".

Arabistan misyonunda görev alan kadın misyonerler gerçekten de kendilerini Arap kadınlarını kullandıkları tuz tedavisine ve bu geleneğin zararlarına karşı eğitmek zorunda hissetmekteydiler. Arap yarımadasında yaşayan yerel Arap halkların yaşamları, coğrafi şartlardan dolayı oldukça basit olmasına rağmen bu halkların kültür ve gelenek ile geliştirdikleri sosyal hayat özellikle kadınların kapanması ve ayırımcılığa uğraması söz konusu olunca oldukça karmaşık bir durum arz etmekteydi. Erken yaşlardaki kız çocuklarının evlendirilmesi, çok eşlilik, genç kızların kendi yaşıtları ile değil de kendilerinden çok yaşlı erkekler ile evlendirilmesi gibi gelenekler bu coğrafyanın nerdeyse her şehrinde hâkim ve oldukça benimsenmiş adetlerdi. Kadınların kapanma için kullandıkları peçe her iki cinsin de 
farklı hayatlar yaşamasına neden olmakta adeta bir sınır vazifesi görmekteydi. Yerel kadınların kapanması, karşı cins ile bir arada bulunmaması, kadınların ayrımcılığa uğraması ve birçok imkândan mahrum kalması, misyonerlerin amaçlarına ulaşması yönünde kendilerine birçok imkân sunmaktaydı. Öncelikle Protestan kadın misyonerlerin bölgedeki yerel Arap kadınları arasında yaptıkları çalışmalar bu misyonerlerin geldikleri ülkelerde bağış toplamak için önemli bir propaganda malzemesi üretmekteydi. Misyonerler, yaptıkları her faaliyeti ağdalı bir şekilde hikayeleştirerek meydana getirdikleri anlatıları çektikleri resimler ile süsleyerek üyesi oldukları organizasyonların merkezine gönderip süreli yayınlarda ve gazetelerde yayınlanmasını sağlayarak kiliseye bağış yapılmasını teşvik etmek için kullanmaktaydı. Diğer taraftan misyon sahasında görevli bayan misyonerlerin ön plana çıkmasını sağlayarak misyonerlik faaliyetlerinde kadının oynayabileceği rolün önemi hakkında bir fikir vererek misyoner örgütlerin kadın misyonerlere daha fazla özen göstermesine neden olmaktaydı. Bunun yanında misyon sahasında kadın misyonerlerin başarılı olması ve bu başarının getirdiği saygınlık özellikle Amerika'da kadın misyoner adaylarının kıta dışı misyonerlik faaliyetlerine katılmaları için ilham verici bir ortam meydana getirerek Arap misyonunun da kadın misyoner adayları içinde öne çıkmasını sağlamaktaydı.

Arap yarımadasında yaşayan yerel kadınların toplum içindeki statülerinin erkekler ile karşılaştırılınca ortaya çıkan olumsuz farkı ve eşitsizliğe rağmen bu kadınların aile içindeki rolü ve özellikle çocukları üzerindeki etkisi göz ardı edilemeyecek bir seviyedeydi. Kadın misyonerlerin sağlık ve eğitim faaliyetlerinin arkasında yatan gerçek nedenin din değiştirme olduğunu idrak eden Arap kadınları, misyonerlerin bu amacına rağmen onlarla iletişimi kesmeyerek sundukları her türlü fırsatı değerlendirmek ve çocuklarını da bu firsatlardan yararlandırmak istiyorlardı. Misyoner okullarında eğitim gören Arap çocuklarına anneleri tarafından verilen telkinler sayesinde çocuklar, misyonerlerin din bilgisi ile ilişskili olmayan her dersi özenle almakta fakat iş din ile ilgili derslere geldiğinde Hristiyanlığa pek fazla ilgi duymadıkları, misyonerler tarafından dilegetirilen gözlemlerdeyeralmaktaydı. Arap kadınları, misyonda görevli her kadın misyonere bu şekilde yaklaşmayı bir adet haline getirerek hem çocuklarının din değiștirmesine engel olmakta hem de misyonerleri gücendirmeden onların sunduğu hizmetleri almaya çalışmaktaydı.

Protestan misyonerlerin Arap misyonunu başlatmasından sonra Arabistan yarımadasına gelmeye bașlayan kadın misyonerler, misyon sahalarındaki yerel Arap kadınlarının hayatlarına dokunarak birçok açıdan değişikliğin yaşanmasını sağladılar. Öncelikle tıp alanında azami bilgiye sahip olan kadın misyonerler, doktor, hemşire ve ebe gibi görevler üstlenerek Arap kadınları arasında başta doğum öncesi ve sonrası olmak üzere yerleșik olan bir takım hastalıklara ve yanlış uygulamalara son vererek modern tıbbın gerekli kıldı̆̆ ilaçlar ve tedavi yöntemlerini Arap kadınlarına sunmaya çalıştılar. Ayrıca erken yaşlarda çocuk ölümlerinin önüne geçmek için den Arap kadınları, çocuk bakımı hakkında misyonerler tarafından bilgilendirilmeye çalışıldı. Bu tür sağlık ve eğitim hizmetleri her ne kadar Arap kadınlarının yaşamında olumlu değişiklikler meydana getirse de gelenekler ve sosyal yapıdan kaynaklanan kadının aile içindeki aşırı iş yükünün meydana getirdiği zorluklar, Arap kadınlarının sıklıkla ölümle sonuçlanan hastalıklara kapılması engellenememişti. 1905 yılında Bahreyn'deki görevi sırasında tifüse yakalanarak vefat eden kadın misyoner Marion Wells anısına misyoner arkadaşları tarafından inşa ettirilen Marion Wells Thoms Memorial kadın hastanesi, aynı yıl Bahreyn'de açılarak türünün ilk örneği olarak bölgedeki Arap kadınlarına hizmet sunmayı hedefledi. Kısa sürede kadın hastalıklarında uzmanlaşan hastaneye Arap yarımadasının 
birçok bölgesinden hasta gelemeye başlamıştı. Hastanenin yönetimi misyoner bir aileden gelen Doktor Easther Barny tarafından yürütülmekteydi (Al-Sayegh, 1998: s. 351-352).

Arabistan yarımadasında, geleneklerin şekillendirdiği Arap toplumun kültürel değişiminde bölgeye İsa'nın müjdesini herkese duyurmak ve Protestan propagandası yapmak amacıyla gönderilen bayan misyonerlerin rolü önemliydi. Kız çocukları arasında eğitimin yaygınlaşması ve bu konuda yeni fikirlerin geliştirilmesi, kendi kendine yeterlilik ve eğitim, sosyal serbestîye ve kadın hakları gibi söylemler, bölgeye misyonerler tarafından tanıştırılmıştı. Amerikalı Protestan misyonerlerin Arap misyonunu kurduğu sırada Arap yarımadasında kız çocuklarının eğitimini geçekleştirecek nerdeyse hiç bir kurum yoktu. Misyonerlerin bu durumu tespiti sonrasında kendi çabaları ile özellikle kız çocuklarının eğitimi ile ilgilenecek biri Bahreyn'de diğeri ise Aden'de iki okul inşa edildi. Bahreyn'deki okul 1904 yılında inşa edildi ve bulunduğu misyon sahası olan Basra Körfezi'nde türünün ilk örneğiydi. Bayan Zwemer tarafından kurulan bu okul, Bayan Zwemer'in fedakâr çalışmaları sonucu kısa zamanda büyüyerek bünyesine yeni binalar kattı ve elde ettiği başarılar sayesinde bu bölgedeki misyonun önemli bir vitrin ürünü haline dönüştü. Yine kız çocuklarının eğitimi için bir diğer kadın misyoner olan Bayan Mylrea, Kuveyt'te bir okul açtı. Modern eğitimin yanında dil öğrenmeyi de mümkün kılan bu okulun misyon sahasındaki tanıtımı sırasında kullanılan vaadeler neticesinde bölgedeki birçok Arap kadını çocuklarını bu okula göndermek istedi fakat sonrasında okulun, öğrencileri Hristiyanlaştırdığını öğrenen bu veliler kendilerini çocuklarını geri çekmek zorunda hissettiler (Calverley, 1958: s. 100/102).

Arap misyonunda görevli kadın misyonerlerin bir diğer önemli görevi de Arap kadınları arasında Protestan propaganda çalışmalarında bulunurken aynı zamanda modern Hristiyan yaşam tarzını da yerel kadınlara benimsetmekti. Arap misyonunda görev alan kadın misyonerler, misyon sahasına geldiklerinde ve ya Amerika ziyaretleri dönüşlerinde misyon sahasındaki yerel kadınların hayatını kolaylaştıran bir takım elektrikli aletlerin yanında manuel çalışan aletler getirip bu aletlerin tanıtımını hem kız okullarında hem de hasta ziyaretlerinde yaparak Hristiyan hayat standardının nasıl yüksek bir seviyede olduğunu göstermeye çalışarak bir özenti meydana getirme beklentisi içindeydiler. Singer dikiş makinesi ve Ford otomobiller Arap yarımadasına misyonerler tarafından getirtilerek Hristiyanların kendi ülkelerinde nasıl rahat yaşadığını ve teknolojik olarak ileri seviyede olduklarının mesajını vererek Protestanlığı seçecek olanların bu tür bir yaşama kavuşmasının mümkün olduğu, misyonerler tarafından dile getirilmekteydi.

Arabistan misyonunun bulunduğu alanlarda yaşayan yerel halkın kültürel değişiminin sağlanması her ne kadar misyonerlik faaliyetlerinin bir sonucu gibi görünse de bu aslında misyonerlerin asıl hedeflerinden biriydi. Bölgede yaşayan Müslüman ağırlıklı nüfusun Protestanlığı tümüyle kabul etmeyeceği konusunda tecrübelerinden elde ettiği bilgi dâhilinde öğrenen misyonerler, hiç olmaz ise bu hakların batı tarzlı bir hayat özentisi içinde olmalarını, batıya karşı bakışlarının daha ılımlı olmasını ve hayat tarzlarının Hristiyan hayat tarzı ile hemen hemen aynı olmasını isteyerek her zaman kültür değişimi hedefini yürürlüğe koyma faaliyeti içinde olduklarını söyleyebiliriz. Kadın misyonerler bu konuda daha fazla özveri içinde olarak misyon sahasına gedikleri ilk andan itibaren hedef kitleleri ile iletişim sağlamak için başta Arapça öğrenip, yerel kadınlar gibi giyinerek onların sempatisini kazanmaya çalıştılar. Kendilerini sadece bir misyoner karısı olarak göstermeyip yeri geldiğinde bir öğretmen, bir hemşire ve yeri geldiğinde bir ev hanımı olabileceğini göstermeye çalışan kadın misyonerler, 
Arap kültürüne adapte olarak propaganda çalışmalarını bu iletişimin çerçevesinde meydana getirmeye çalıştılar. Protestanlığa kazanım sağlama konusunda yaşadıkları başarısızlık kadın misyonerlerin hiç bir zaman umudunu yitirmesine neden olmayıp aksine Arap kadınlar ile olan iletişimlerini daha iyi bir konuma taşımak için kendilerine Arap isimleri bile kullanmayı denediler. Bu çabaları ileride meyvesini vererek yerel Arap kadınların bu misyoner kadınları artık kendi toplumlarından biri olarak görmeye başladıkları, misyoner yazınlarında dile getirilerek kadın misyonerlerin özellikle bölgedeki Arap kadınları üzerinde önemli bir etkisinin olduğu belirtilmekteydi.

\section{Arabistan misyonuna bekâr bayan misyonerlerin gelişleri}

Hem coğrafik alan hem de kurumsal olarak gelişmeye devam eden Arabistan misyonu, giderek bir kadın misyoner hareketine dönüşmesine sahne olmaya başlamıştı. Misyonda görevli kadın misyonerlerin yerel kadınlar ve kız çocukları arasındaki sağlık ve eğitim faaliyetleri misyonun daha çok bu kesimine eğilmesine neden olarak kadın misyonerler üzerindeki yükü bir hayli artırmıştı. Özellikle bölgede gelecekte oluşması misyonerlerce ümit edilen Protestan neslin temelinin hazırlanması için yerel kadın ve kız çocuklarının eğitimi Protestan misyonunun odaklandığı nokta haline dönüşmüş ve misyonun bayan personel ihtiyacı her zamankinden daha fazla hissedilir olmuştu. Bu nedenlerden dolayı Arabistan misyonu 1918 yılından itibaren ikinci evresini yaşamaya başlamıștı. Bu evre, 1939 yılına kadar sürecekti. Bu dönem zarfında Arabistan misyonunu önceki dönemden farklı kılan özellik ise misyona bekâr bayan misyonerlerin gelmeye başlamasıydı. Önceki dönem olan kuruluş döneminde misyondaki kadın misyonerlerin tümü misyoner eşi olarak bölgede bulunmakta ve propaganda faaliyetlerini eşi ile birlikte gerçekleştirmekteydi. Yerel kadın ve kız çocukları arasında misyonerlik faaliyetlerinin beklentiler doğrultusunda dönüt sağladığını gören misyonun Amerika'daki merkezi, yeni stratejiler belirleyerek bu amaç doğrultusunda bekâr bayan misyonerlerin bölgeye gönderilmesi için istihdam atağını başlattı. İyi donanımlı, dil bilen, sağlık sorunu olmayan ve en az beş yıl evlenmeyeceği vaadini veren genç misyoner adayları Arabistan misyonuna gönderilmeye başlandı. Misyonerlerin özellikle bekâr bayanlardan seçilmesi ve uzun bir süre evlenmeyeceği sözünün örgüt tarafından alınmasının ardında yatan neden ise misyon sahasında daha çok kadın ve kız çocukları arasında etkin bir misyonerlik görevinin icra edilebilmesinin yolunu açmaktı. Evli kadın misyonerlerin, çocuklarından ve eşinden dolayı eve bağlı kalmaları misyonerlerin diğer istasyonlarına vakit ayıramaması, yeterli ölçüde dua faaliyetlerinin gerçekleştirilememesi gibi konuları Protestanlığa kazandırılan kişi sayısının azlığına bağlayan misyon merkezi bu eksikliklerin giderilmesi için bekâr bayan misyonerlerin istihdamına önem vermekteydi. Misyonerlerden özellikle en az beş yıl evlenmemeleri vaadinin alınması ile özverili bir çalışmayı hedefleyen örgüt bu konuda oldukça kesin kurallar koyarak bayan misyonerlerden hat safhada istifade etmeyi beklemekteydi. Arap misyonuna daha önceden de bekâr bayan misyonerlerin gelmişliği bulunmaktaydı fakat bu misyonerlerin kısa sürede bölgede petrol işinde bulunan zengin Amerikalı ve İngilizler ile evlenmesi misyonun faaliyetlerinin yarım kalması deneyimini yaşayan örgüt sahip olduğu misyonerleri kısa sürede kaptırmamak için misyonerleri istihdam etmeden yazılı olarak bu sözü kendilerinden almaktaydı (Al-Sayegh, 1998: s. 347/349). Ayrıca sözünü tutmayan misyonerlerinde kiliseye olan üyeliğini feshederek adeta bir aforoz mekanizması oluşturup Arabistan misyonunda görevli misyonerlerin misyon sahasında azami ölçüde kalmasını sağlamaktaydı. Kendisine has bir evlilik sistemi de geliştiren örgüt, bekâr bayan misyonerleri kaptırmamak için beş yıl sonra evlenme yasağı sona eren 
misyonerleri erkek misyonerler ile iletişim kurmasını sağlayarak örgüt dâhilinde kalmasını sağlamaya çalışmaktaydı (Dalenberg, 1989: s. 43/46). Örgütün misyoner istihdamını bu şekilde sıkı tutmasına rağmen, yabancı ülkelerde bulunan misyonlarda Protestanlı̆̆ yaymak amacıyla örgüte hizmet etmek için başvuruda bulunan bekâr bayan misyonerlerin sayısı her geçen gün artmaktaydı. Kendisini kanıtlamak isteyen, macera arayan, dış ülkeleri merak eden ve feminist duygulara sahip genç bayan misyoner adayları dış misyonlarda kariyer sahibi olmak için o dönemin trendi olan dış ülkelerde misyoner olma akımına kendilerini kaptırarak Protestan misyoner örgütlerin kapılarını çalmaktaydı. Bu trendin en fazla hissedildiği ülke Amerika olmasına rağmen aynı zamanda özellikle kuzey Avrupa ülkelerinde de kendisini hissettirmekteydi. Nerdeyse bütün ömrünü misyonerlik faaliyetlerine adamayı hedefleyen bekâr bayan misyonerler, hayat boyu sürecek olan bu kariyerlerinde bir kahraman olarak anılmak için canla başla çalışacaklardı. Arabistan misyonu da bu trendden nasibini alarak 1819-1940 yılları arasında hatırı sayılacak ölçüde bekâr bayan misyonerlerin akınına uğrayacaktı. Öyleki misyonda görevli olan bekâr ve evli bayan misyonerlerin sayısı erkek misyonerlerin sayısını bir hayli geçecekti (Allison, Shaw, 1994: s. 75/78).

$\mathrm{Bu}$ dönem aralığında Arabistan misyonuna üç meslek dalında uzman, sağlıklı ve misyonerlik faaliyetlerinde fedakârlıktan çekinmeyen misyoner adayları istihdam edilmeye çalışıldı. Arap misyonunun merkez ve dış istasyonlarında kurulan okullarda kadın ve kız çocuklarına eğitim vermek amacıyla öğretmen, ev ziyaretlerini düzenli bir şekilde gerçekleştirip bu ziyaretler sırasında İncil okunması, basit okuma ve yazma faaliyetleri ve Hristiyan yaşam şeklinin tanıtılması konusunda usta öğreticiler ve misyonun hastane ve dispanserlerinde çalışacak olan doktor, hemşire ve ebeler örgüt tarafından istihdam edilerek Arabistan misyonunun çeşitli merkezlerine gönderildi. Örgütün üzerinde durduğu bir diğer nokta ise sahaya gönderilen bu genç misyonerlere yardımcı olmak amacıyla yerel halktan misyonerlik faaliyetlerinde kullanılacak ara elemanların yetiștirilmesi konusuydu. Misyoner yardımcılarının yerel halktan seçilip yetiştirilmesinin sağlayabileceği birçok avantajın olduğunu düşünen örgüt, başta misyonerlerin yerel halk ile kısa sürede iletişim kurmasını sağlayabilmeleri ve yerel halkın misyonerlere kendilerinden biriymiş gibi davranıp yabancılık çekmemeleri konusunda ve son olarak misyonerlerin kısa sürede dil öğrenmelerine yardımcı olabileceğini düşünmekteydi. Bu dönemde bölgedeki misyoner okullarında zeki ve çabuk kavrayan kız öğrencilerin misyonerler tarafından özellikle hasta bakıcı ve hemşire olarak yetiștirilmeye çalışılarak misyona bağlı hastane ve dispanserlerde görevlendirilmeye başlanıldı. Bekâr bayan misyonerlerin Arabistan misyonunda gönderildikleri alanlarda hali hazırda evli kadın misyonerler çalışmalarına da devam etmekteydi. Yeni gelen misyonerler kendilerinden daha tecrübeli olan evli misyonerlerin yanında adeta bir staj görme edası ve ciddiyeti içerisinde eğitim almaya başladılar. Misyonerlik faaliyetlerinin yoğun olarak yaşandığı yarımadanın Basra Körfezi’nin kıyı kesimlerinde yer alan Bahreyn, Kuveyt ve Umman bölgelerinin her birinde birden fazla bir bayan misyonerin idare ettiği misyon kurumu yer almaktaydı. Misyona yeni katılan bekâr bayan misyonerler bu kurumlara yerleştirerek yönetimi devralmaya başlayacaklardı. Fakat öncelikli aşılması gereken sorun dil sorunuydu. Bu nedenle bekâr bayan misyoner adayları kendilerinden çok daha önce bölgeye intikal etmiş ve bir hayli tecrübe sahibi olan meslektaşlarından aldıkları dil dersleri sonucunda adeta dil sınavından başarılı olmuşçasına bir icazet aldıktan sonra bağımsız olarak çalışmalarına devam edebilmekteydiler.

Arabistan misyonuna katılan bekâr bayan misyonerlerden biri de kendisine sonradan 
yerel halk tarafından Şerife isminin verileceği Bayan Cornelia Dalenberg adlı misyonerdi. Bayan Cornelia, örgütün benimsediği yeni stratejiye uygun olarak oluşturduğu istihdam politikasının hemen sonrasında misyona kabul edilip Arabistan'a gönderilen ilk misyonerlerden biriydi. Arap topraklarına doğru yolculuğu sırasında yanında kardeş olan iki genç bayan daha bulunmaktaydı. Ruth ve Rachel Jackson adlı misyoner kardeşler ile Bayan Cornelia 1920'li yılların başında Arabistan misyonunda görevlerine başlamış olup bölgedeki yerel kadın ve kız çocuklarına Protestanlığı öğretmek ve kabul ettirmek için bu topraklarda kırk yıl hizmet vereceklerdi. Öğretmen ve İncil okuyucu meslek gurubu altında misyonda hizmet vermeye çalışan Jackson kardeşlere nazaran Bayan Cornelia, bir hemşire olarak misyonda görev üstlenmişti. Mudhakkirat Şerife al- Amerikaniyah adlı Arapça basılan hatıratında, Bayan Cornelia 19201930 yılları arasında Arap yaşamı hakkında bilgi vermekteydi. Eserinde Arap kadının yaşamına değinen Bayan Cornelia, Arap coğrafyasında kadının ne tür bir statüye sahip olduğunu, kapanmanın ne anlama geldiğini, kadınların çektikleri zorlukların neler olduğu ve Arap aile yaşamında kadınların sosyal ilişkilerdeki üstün gücünü vurgulamaya çalışmaktaydı (Dalenberg, 1989: s. 145/150).

$\mathrm{Bu}$ dönem zarfında Arabistan misyonunun acil karşılanması gereken ihtiyaçlardan en önemlisini doktor misyoner istihdamı meydana getirmekteydi. Örgüt, Arabistan misyonunda gerçek başarısını sağlık alanındaki faaliyetleri ile elde etmeyi planlamaktaydı. Misyon sahasının çeşitli alanlarında açlan hastaneler ve dispanserlerde her ne kadar yeterli ölçüde hemşire ve ebe gibi yardımcı misyonerler görev yapmakta olsalar dahi bu gibi kurumlardaki doktor yetersizliği hastaların misyon kurumları ile olan ilişkisini olumsuz yönde etkilemekteydi. $\mathrm{Bu}$ nedenle örgüt, özellikle izin için Amerika'ya gelen genç kadın misyonerleri bu izinleri sırasında Tıp Kolejlerinde açılan hızlandırılmış kurslara başvurmalarını öğütleyerek sahip oldukları yeterlilikleri artırma ve geliştirmeleri yönünde teşvik etmekteydi. Arabistan misyon sahasındaki yaygın hastalıklar ile mücadele edilmesi bölgede yetkin kişilerin hizmeti ile aşılacağını öngören örgüt, özellikle bu tür hastalıklardan şikâyeti olan kadın kitlesi arasında hem tedavi hem de dini faaliyetler yürütecek bayan doktor misyonerlere ihtiyaç duymaktaydı. Bayan Cornelia da tatil için Amerika'ya geri dönüp bu tür eğitimlerden alan bir misyonerdi. Üç aylık bir eğitimin sonunda Bayan Cornelia tekrar Arabistan misyonuna hemşire olarak geri döndü. Fakat yalnız olarak değil Arabistan misyonunda çalışmayı kabul eden genç bir doktor bayan arkadaşıyla (Dalenberg, 1989: s. 130/140).

Bayan Cornelia anılarında sadece görev yaptığı alandaki sosyal yapıya ve kadının bu yapı içerisindeki rolüne değinmekle kalmıyor aynı zamanda misyon sahası olan Bahreyn'deki eğitim faaliyetlerine de değinerek özellikle kız çocukları için açılan okulların bölgenin kaderini değiştirebilecek bir potansiyele sahip olduğunu vurgulamaktaydı. Diğer taraftan kız çocuklarına misyonun açtı̆̆ı sağlık meslek okullarında eğitim verilerek misyon hastanelerinde görevlendirildiklerini ve bu tür okulların aileler arasında giderek popülerleştiğini belirten Bayan Cornelia aynı zamanda Bahreyn'de bir hemşire okulunun da bu yıllarda öğrenci kaydetmeye başladığını açıklamaktaydı. Bayan Cornelia, bu tür okullardan mezun olacak öğrencilerin kendi toplumlarına hizmet etmeye başlaması bölgenin gelişimi ve toplumdaki kadın statüsünün yükselmesi açısından önemli olduğunu vurgulamakla birlikte misyonerlerin halk tarafından benimsenmesi daha da ötesi Protestanlığın kabul görmeye başlamasını daha fazla ümit ettiğini anılarında göstermeye çalışmaktaydı (Dalenberg, 1989: s. 250/260).

$\mathrm{Bu}$ dönem aralığında Arabistan misyonu, faaliyet sahasında farklı bir gelişmeye 
sahne olmaktaydı. Petrolün bulunuşu özellikle misyonun yoğun olarak konuşlandığı yarımadanın Basra Körfezi kesimindeki kısmı, önemli değişimler yaşamak zorunda kaldı. Misyonun merkez üslerinden biri olan Bahreyn, 1932'de dünyada petrol ihraç eden ilk devlet oldu. Hemen ardından 1934 yılında Suudi Arabistan da petrol ihraç etmeye başladı. Petrolün bulunması ve para kazandıracak bir eşyaya dönüşmesi körfez ülkelerinin yaşam standartlarında değişimlere neden oldu. Modern yaşamın metaları Arap yaşamına da girmeye başladı. Elektrik, Radyo, ulaşım alanındaki modernizasyon ve alt yapı çalışmaları bu bölgede yaşamın önemli vazgeçilmezleri arasına girmeye başladı. Bölgede petrol ile başlayan değişim misyonerlik faaliyetlerine de yansıdı. Teknolojinin gelişmesi ile birlikte ve bu teknolojinin dünyanın bu bölgesinde de ulaşım olanaklarının gelişmesi ile yer bulmaya başlaması başta misyonerlik faaliyetlerinde kullanılan araçların değişiminde büyük rol oynayarak misyonun geleneksel yöntemleri bir kenara bırakıp yeni stratejiler benimsemesi ihtiyacını hissettirmeye başladı. Elbetteki başta ev ziyaretleri, sağlık ve eğitim alanındaki kemikleşmiş faaliyet yapısı devam ettirilecekti fakat bu faaliyetlerde kullanılan materyal ve müfredat ise çağın yeniliklerine paralel olarak revize edilecekti. Bölgede meydana gelen sanayi gelişiminin hızlı bir büyüme içerisine girmesiyle ortaya çıkan kurumların personel ihtiyacı, bölgedeki yabancı yatırımcıların çoğalmasıyla meydana gelen yatırımcı topluluğunun yerleşik hayat tarzını benimsemesiyle ihtiyaç duymaya başladıkları hizmet elamanı ihtiyacı, misyonerlik faaliyetlerinin şekillenmesinde ve eğitime daha fazla önem vermesine neden oldu. Bu nedenle, bölgedeki misyonerler dil, sağlık ve meslek alanlarında yeni okullar meydana getirmeye çalışarak bölgenin değişen şartlarına ayak uydurmaya çalıştılar. Protestanlığa adam kazanma bu faaliyetlerin en tepe noktasındaki amaç olma özelliğini her zaman korudu. Arabistan misyonunun hedef kitlesi olan Müslümanlar arasında bu kadar faaliyete rağmen Protestanlı̆̆ı seçenlerin sayısı hiç de misyonerlerin umduğu bir seviyeyi yakalamamış olması misyonerleri hayal kırıklığına uğratsa da bölge halklarının batı medeniyeti tesirinde kalması, batıya her zaman özlem duyması ve batının üstünlüğünü kabul etmesi misyonerler için önemliydi. Çünkü batı Hristiyan'dı. Mücadeleyi adeta bir din mücadelesi gibi gören misyonerler Hristiyanlığın, daha doğrusu Protestanlığın İslamiyet'e karşı olan üstünlügünü misyonerlik faaliyetlerinin her aşamasında ortaya koymaya çalışarak Protestanlığı kendi dini olarak benimseyecek herkesin bu gelişimin, bu üstünlüğün bir parçası olma hissini Müslümanların kalplerinde oluşturmaya çalışarak belki ileride bu dini benimseyecekleri ümidini hep taşıyarak mücadelelerine devam etmeye çalıştılar (Storm, 1938: s. 90/95).

1920'li yıllardan sonra Arabistan misyonunun yayılım alanı oldukça genişlemeye başladı. Misyonun daha önceden merkezlerini kurduğu Bahreyn, Kuveyt ve Umman'dan sonra Suudi Arabistan'ın farklı şehirleri örgütün yeni hedefleri arasında yerini almaya başladı. Bahreyn'e olan yakınlığından dolayı Al-Katif ve Hufuf şehirlerinde Amerikan misyonunun dış istasyonları meydana getirildi. Bu bölgede görevlendirilen misyonerler aynı zamanda Arabistan yarımadasının doğu sahilindeki şehirleri de ziyaret etmeye başlamıştı. Misyon merkezindeki görevlerinden arta kalan zamanlarda misyonerler çevre bölgelerdeki yerleşim alanlarını ziyaret etmeyi ve misyon için gelecek vaat eden yerlerin tespitini yapmak amacıyla bu ziyaretlere büyük önem vermekteydi. Gittikleri alanlarda hoş karşılanan misyonerler, özellikle sundukları sağlık hizmeti nedeniyle bölgenin yöneticileri tarafından da nezaket ile bakılmaktaydı. Bu dönemde Necef çölünün çevresinde ve içinde bulunan yerleşim alanlarının tümünü ziyaret eden misyonerler sonrasında Hicaz bölgesini ve Al Hassa bölgesini ziyaret etmişlerdi. Ziyaretleri gerçekleştiren misyonerlerin çoğu sağlık alanında yetkinliklere sahip olup yerel halkın samimiyetini ihtiyacı oldukları sağlık ve ilaç hizmetini gidermekle 
kazanmaya çalışırken aynı zamanda bu misyonerlerin yanında getirdikleri İncil okuma ve öğretme görevini üstlenen misyonerler de boş durmayıp görevini icra ederek Protestanlık propagandasını yapmaktan geri kalmamaktaydılar.

1929-1934 yılları arası Arabistan yarımadasındaki Protestan Amerikan misyonu için oldukça sıkıntılı bir zaman dilimiydi. Bu yıllarda Amerika'da yaşanılan ekonomik bulanım misyona da yansıyarak misyonun ekonomik kriz yaşamasına neden olarak yeni misyonerlerin bölgeye intikal etmesini engellemişti. Ekonomide süregelen durgunluk misyonun genişlemesini de tehdit etmekle beraber kaynakların kısıtlı hale gelmesi misyonun yeni istasyonlar oluşturmasına engel olmakla kalmadı hatta misyonun küçülme politikasını uygulamaya koymasına da sebebiyet verdi. Arabistan misyonunda uzun süreden beri görev yapan tecrübeli misyonerlerden bazıları yaşanılan bu ekonomik kriz sürecinden olumsuz etkilenerek misyondaki görevine kendi istekleri dâhilinde son vererek Amerika'ya geri döndüler. Bu misyonerlerin tekrar misyon sahasına dönüp misyonu yeniden canlandırmaları 1932'den sonra gerçekleşebildi (Boersma, 1991: s. 2/4). Bu süreç zarfında Arabistan misyonuna hiç bir yeni misyonerin gelmediğini söylemek doğru değildir. Doktor Mary Bruins Allison, misyonun bu dönemde kadrosuna kattığı yeni misyonerlerden biriydi. 1934 yılında Basra körfezindeki Amerikan misyonuna katılan Allison, görev yeri olan Kuveyt'te atandı. 1934 yılında Kuveyt'in ekonomisi gerilemiş, şehir adeta arkasındaki çöl bölgesi ile deniz arasında sıkışmış bir şehir görünümündeydi. 1930’lu yıllara kadar Kuveyt, körfezdeki diğer ülkeler gibi ekonomisini bölgede çıkan inci üzerine kurmuş fakat bu dönemde Japonya'nın ürettiği suni incilerin piyasada dolaşıma girmesine karşı gelememiş ve ekonomisi bozulmaya yüz tutmuştu. Ancak bu dönem, Kuveyt için yeni bir sürecin başlangıcının da habercisiydi. Amerikan ve İngiliz Petrol şirketlerinin yatırımcıları petrol araştırmaları için Kuveyt'te bulunmaktaydı. Doktor Allison, Kuveyt'te kaldığı süre zarfında kaleme aldığı hatıratı olan Doctor Mary in Arabia adlı eserde 1930-1940 yılları arasında bölgenin ekonomik gelișiminin yanında sosyal yapı, kadının toplum içindeki yeri ve süreç içindeki gelişimi hakkında bilgiler vermektedir. Kuveyt'in yakın tarihi hakkında çok değerli bilgiler içeren bu kitap araştırmacılara önemli bilgiler sunması açısından önemli olmakla birlikte misyonerlerin bu tür yazım faaliyeti içinde olması da misyonerlik faaliyetlerinin tarihe olumlu katkısı olarak da görülebilir (Allison, Shaw, 1994). Kuveyt'te geldiği sırada sadece arkadaşlarının ve bir kaç Protestan dindarın desteğiyle geçinmeye çalışan Doktor Allison, örgütün mali sıkıntı içinde olmasından dolayı örgütten maaş bile alamadı. Geri kalan hayatının tümünü misyonerlik faaliyetlerine karşılık beklemeden adayan Doktor Allison, kısa sürede yerel halkın desteğini ve sevgisini kazanarak Kuveyt bölgesinde Protestan misyoner varlığının oluşumuna önemli ölçüde katkı sağladı. Doktor Allison, 1934 yılında misyonun Kuveyt merkezine geldiği sırada, bölgeye daha önce gelmiş misyonerler olan hemşire Bayan Mary Van Pelt ve hemşire Bayan Mylrea ile birlikte çalışmaya başladı. Mary Van Pelt, Kuveyt'te 1919 yılında gelmiş ve kendisinden önce Kuveyt misyonunun yöneticisi olan Easter Burny'in ayrılmasıyla misyon yönetimini devralarak misyonun kadınlar arasındaki faaliyetlerini yürütmekteydi. 1930 yılına gelindiğinde Kuveyt misyonu birçok misyoner aileye ev sahipliği yapmaktaydı (Al-Sayegh, 1998: s. 347/349).

Arabistan yarımadasındaki Protestan Amerikan misyonunun karşılaştığı sorunlardan biri bekâr bayan misyonerlerin örgütün isteği dışında ve örgütün erkek misyoner üyelerinden hariç olan kişiler ile evlenerek misyondan ayrılması sorunuydu. Örgüt bu durumu engellemek ve misyon işlerinin yarım kalmasının önüne geçmek için kilise üyeliğinden çıkarılma gibi cezalar gündeme getirmeye çalışarak bayan misyonerlerin erkek misyonerler ile 
evlenmelerine en az beş yıl bekâr olarak misyonda çalıştıktan sonra izin vermekteydi. Fakat bölgeye petrol sanayisi için gelen iş adamlarından bazıları bekâr bayan misyonerler ile evlilik geçekleştirmeye çalışmışlardı. 1937 yılına kadar Kuveyt misyonundaki görevini bekâr olarak sürdüren bayan misyoner Mary Bruins de bu evlilik kervanına katılan misyonerlerden biriydi. 1937'de hayatını Kuveyt'te İngiliz Petrol Şirketi olan Kuveyt Oil Company'de çalışan bir İngiliz ile birleştirmek isteyen Mary Bruins, bu fikrini örgüte açtığında örgütün şaşkınlık veren itirazıyla karşılaştı. Bu itiraza karşı bayan misyonerlerin erkek misyonerlerden daha başarılı olduğunu ve erkek misyonerlerin sahip olduğu serbestlikten muaf olmasını anlamadığını belirterek evlilik kararını aldı. Evliliğiyle misyonerlik faaliyetini birlikte yürütmeyi planlayan misyoner Mary Bruins, bu planında başarısız olunca eşiyle birlikte Hindistan'a yerleşti. Fakat evlilik uzun süremedi çift 1940 yılında ayrıldı ve kadın misyoner Mary Bruins, Arabistan misyonuna tekrar geri dönerek sağlı alanındaki faaliyetlerine yirmi yıl daha devam etti (Allison, Shaw, 1994: s. 74/79).

Karşılaşılan her türlü soruna göğüs germeyi başaran Arabistan misyonu, bölgedeki varlığını koruyarak misyonerlik faaliyetlerine devam etti. Bölgedeki yerel kadın ve kız çocukları arasında erkek ve kadın misyonerlerin gerçekleştirdiği eğitim ve sağlık hizmetleri aksamadan ilerleyerek yeni açlan okul ve hastanelerin yanında modern yetimhaneler de devreye sokularak özellikle toplumun kadın kesimi üzerinde misyonunun bir etki elde etmesi sağlatıldı. Protestan yaşam tarzı ve Protestan İncilinin tanıtılarak yerel halk tarafından okunmasının sağlatılmasının yanında Hristiyan kültürünün ne olduğu hakkında yapılan ziyaretler sirasında ortaya konulan sunumlar ve yapılan sohbetler esnasinda halkın bilinçlendirilmesine büyük önem verildi. Misyonun en başarılı olduğu sağlık alanında sadece 1934 yılı içinde 37.000 'e yakın hasta tedavi edildi. Hastane ve dispansere gelen hastalara eğitim verilerek özellikle kadın ve kız çocukları arasında yaygın olan hastalıklara dikkat çekilerek bu hastalıklara karşı yapılması gerekenler hakkında bir bilinç oluşturulmaya çalışıldı. Diğer taraftan doğum sırasında yaşanılan kadın ölümlerinde büyük bir azalıș söz konusu idi. Misyonerler sadece hastalıklar ile ilgilenmeyip bu hastalıkların çevrede hâkim konumda olmasını sağlayan alt yapı eksikliklerine de el atarak misyon sahasında alt yapıdan ötürü yaşanılan sağlık sorunlarının azaltılması için fon oluşturup toplanılan para ile hem bu eksiklikleri gidermeye çalışmaktaydılar hem de yeni hastane binaları inşa ediyorlardı. Örneğin 1939 yılında misyonerler tarafından sadece bayan hastalıkları ve doğum ile ilgi olacak bir hastaneyi bu fon sayesinde inșa edip Kuveyt Şeyhi tarafından açılışının yapılmasını sağladılar. Kuveyt'te kendi alanında ilk olan bu misyon kuruluşunun sadece Kuveyt'teki hastalara değil tüm körfez ülkelerindeki hastalara da açık olacağı belirtilerek misyonerlik faaliyetlerinin henüz dokunmadığı bölge ülkelerinin de misyonun hedefinde olduğunu tahmin etmek güç olmasa gerek (Al-Sayegh, 1998: s. 350).

1939 yılına gelindiğinde Arabistan misyonu kuruluşunun 50. yılını kutladı. Bu yıl, bölgedeki Protestan Amerikan misyonu misyonerlik faaliyetlerinde gelebileceği en son noktaya ulaştığı yıldı. Bu yıllarda misyon bir gurup kolej mezunu bayan misyoner tarafından idare edilmekle birlikte bölgenin ziyaret edilmedik bir kısmı kalmamış nerdeyse her kalbe dokunulmuş olmaktan duyulan bir memnuniyet vardı misyonerler arasında. 


\section{Profesyonel kadın misyonerlerin Arabistan misyonuna dâhil olması}

Yoğun olarak Basra Körfezi'nde konuşlanan Arabistan misyonunun son dönemini oluşturan 1939-1973 yılları arasındaki sürecin başlamasıyla birlikte misyonda görevli Protestan misyonerler arasında bir düşünce hâkim olmaya başladı. Yerel halkı Protestanlığa kazandırmak amacıyla bölgede bulunan misyonerler, yerel halk arasında gerçekleştirdikleri insani yardım, eğitim ve sağlık alanındaki faaliyetlerden asıl görevleri olan Protestan propagandası yapmak ve insan kazanmak faaliyetlerine yeteri kadar zaman ayıramadıkları düşüncesini gündeme getirmeye başladılar (Dalyan, 2011). Misyonun hedef kitlesinin önemli bir bölümünü oluşturan yerel kadın ve kız çocuklarının eğitim ve sağlık ihtiyaçlarına cevap vermenin misyonerleri oldukça yorduğunu, zamanlarının büyük bir bölümünü ve enerjilerinin önemli bir kısmını bu ihtiyaçları karşılama uğrunda harcadıklarını gören örgüt, kadın misyoner istihdamında farklı bir yol izlemeye başlayarak eğitim seviyesi yüksek ve ihtiyaç duyulan yeteneklere sahip misyonerleri seçici bir tavırla istihdam etmeye başladı. Görevlendirilmek için kendisine başvuran bütün misyonerlerin kolej mezunu olmalarını şart koșan örgüt bu stratejisi ile misyon sahasındaki halkın yeteri ölçüde misyonerler tarafından belli bir medeniyet seviyesine getirildiğini ve bundan sonraki aşamanın ise Protestanlığın bu coğrafyada yayılması olduğunu düşünmeye başlamıştı. Örgütün misyoner alımı sırasında dikkat etmeye başladığı misyoner adaylarının mezuniyet ve akademik geçmişi ayrıntılı bir şekilde incelenerek ancak eğitimi en yüksek adayların misyona kabulünün gerçekleştiği ve kabul şartlarının giderek zorlaştığı bir dönemde kadın misyoner adaylarının başvuru sayısında herhangi bir düşüş yaşanmamaktaydı. Kıta dışı misyon alanlarının sahip olduğu gizem ve çekiciliğe ek olarak bu misyonlarda görev almış ve yaptığı icraatlar ile Amerika' daki misyonerlerarasındadilden dile dolaşan kadın misyonerlerin sahipolmayabaşladığı popülarite de eklenirse misyonerlerin yabancı diyarlarda çalışma isteği hiç bir şekilde azalmamıştı. Ayrıca Arap misyonunda görevli kadın misyonerlerin sayısı erkek meslektaşlarından bir hayli fazla olması ve misyonun daha çok yerel kadın ve kız çocukları arasında faaliyet göstermesi sonucu kadın misyonerlerin sahip olduğu önem, Arabistan misyonu daha çok kadın misyoner hareketine de dönüștürdüğünü bu nedenle kadın misyoner adaylarının bu misyona daha fazla ilgi göstermesine de yol açtığını iddia etmek yerinde olacaktır. Kadın misyonerlerin misyonerlik görevinde gönüllülük esasına erkek misyonerlerden daha fazla sahip çıkmasının yanında yüz yıl önce Amerika'da gerçekleșen dinde uyanış sürecinde Protestanlığın öne çıkarak Amerikan toplumunda birleștirici bir rol üstlenmesinde kadınların sahip olduğu inancın ve gayretin farkında olan örgüt, kadın misyoner istihdamına büyük önem vermekteydi (Al-Sayegh, 1998: s. 351/352).

Arabistan misyonunun son evresinde misyona katılan bayan misyonerlerden biri olan Jeanetta Boersma, hemşire olarak 1940 yılında misyon sahasına geldi. Hayatını adadığı misyondaki faaliyetleri sırasında yerel kadınlar ile kurduğu olumlu ilişki kendisinin halk tarafından "Naima" olarak bilinmesini sağladı. Grace and Gulf adlı kitabında misyonerlik faaliyetleri sırasında yazdığı hatıralarını yayımlayan Jeanetta Boersma, Protestan Amerikan misyonunun Arap yarımadasındaki misyonerlik faaliyetlerinde neden başarılı ve neden başarısız olduğunu tartışarak misyonerlerin bu kadar özverili ve sebat içinde çalışmasına rağmen neden Protestanlığı kabul eden Müslümanın olmadığı sorusunu sorarak misyonu eleştirmekte ve bu soruya cevap olarak da misyonun Arabistan'ın iç kısımlarına yayılması gerektiğini belirterek Protestanlığı kabul edeceklerin iç kısımlarda yaşayan halklar olabileceğini iddia etmekteydi (Boersma, 1991: s. 5/8). Hali hazırda örgüt, körfez ülkeleri 
bașta olmak üzere Arabistan yarımadasının özellikle doğu sahilindeki șehir ve kasabalarda misyonerlik faaliyetlerini sürdürmekteydi hatta hemşire misyoner Jeanetta Boersma'ın geldiği sıralarda bile örgütün misyonerleri, Arabistan içlerine doğru gezilerini başlatmışlardı. Örneğin Irak'ın Amarah şehrinden Muskat'ta kadar olan bölgede örgüt iyi donanımlı beş yeni istasyon kurmuştu. Fakat misyonerlik faaliyetlerini ve bu paralellikte açılan misyon kurumlarının çoğu Basra Körfezi çevresindeki ülkelerde gerçekleştiğini örgüt de kabul etmekteydi. Bu nedenle Arabistan yarımadasının iç kısımlarında Amerikan misyonunun gerçek bir etkinliği bulunmamakla birlikte bu bölgedeki halklara gerçek anlamda dokunulmamıştı. Yukarıda da belirttiğimiz gibi misyonerlerin iç bölgeleri ziyaretleri daha önceden gerçekleşmişti fakat hiç bir Amerikalı misyoner ne erkek ne de kadın, iç bölgelerde misyonun gelişmesi için kalmayıp hepsi körfezdeki misyon merkezlerine geri dönmüştü.

Hemşire misyoner Bayan Jeanetta Boersma'nın 1944 yılında misyona katılmasından kısa bir süre sonra örgüt, misyona yeni alınacak herhangi bir meslek dalındaki misyonerlerin bölgede misyonerlik faaliyetlerine başlamadan önce Arapça dil eğitimi almalarını ve bu eğitimin sonunda oldukça zor olan bir dil sınavını geçmelerini zorunlu kılmıştı. Jeanetta Boersmada bu dil eğitimini almaya mecbur edilmiş misyonerlerden biriydi. Dil eğitimini almak için Umman'da görevlendirilecek misyoner çift olan Jay Kapenga ve Bayan Midge Kapenga ile birlikte çalışan Jeanetta Boersma, misyonerlik görevi için daha sonra Irak, Bahreyn ve Umman'da bulunacaktı. 1950 yılında, Umman'daki görevine başlayan Bayan Jeanetta Boersma, deneyimlerini anlattığı eserinde kalifiyeli misyoner eksikliğinden yakınarak özellikle misyon hastanelerinde görev alacak hemşire, ebe ve hasta bakıcı pozisyonlarının eleman eksikliğinden dolayı boş kaldığını bu hastanelerde görevli doktorlara yardım edecek kimsenin bulunmadığını vurgulamaya çalışmaktaydı. Amerikan misyonunun iki hastanesinin Umman'da bulunmasına rağmen ve bu hastanelerde çalışan misyonerlerin nerdeyse yirmi yıldan fazla bir süre bu bölgede hizmet vermiş olmasıyla yaşlı misyonerlerin yerini alacak özellikle bayan misyonerlerin azlığından dolayı bu bölgedeki misyonerlik faaliyetlerinde pek fazla ilerleme kaydedilemiyordu (Boersma, 1991: s. 82/85). Örgüt, bu nedenden dolayı misyoner Bayan Jeanetta Boersma'yı Umman'a göndererek Muskat'taki yerel kadınlar arasında misyonerlik faaliyetleri yürütmek için Umman misyonunda görevlendirdi.

Umman, Amerikan misyonunun Arap yarımadasındaki önemli üslerinden biriydi. Bu bölgeye misyon yatırımı her geçen gün hız kazanmaktaydı. Misyonerlerin Umman bölgesine yönlendirilişi de yatırımlar paralelliğinde artmaktaydı. Umman'daki yerel kadın ve kız çocuklarının eğitilerek Protestanlığa kazandırılması misyonun nihai hedefleri arasında almasına rağmen sağlık alanındaki faaliyetlere de önem verilmekteydi. Hemşire misyoner adayı Jeanetta Boersma, misyon tarafından Umman misyonuna gönderildiği sırada başka misyonerlerde bu bölgeye doğru hareket halindeydi. Doktor Wells Thoms ve eşi Beth de misyoner bir çift olarak bölgede bulunmakta ve Jeanetta Boersma ile birlikte çalışmalara başlayacaktı. Bu misyoner takımına sonradan Jay and Midge Kapenga adlı misyoner çift katılarak Umman'da yirmi yıldan fazla bir süre Protestan misyonerlik faaliyetleri içerisinde olacaklardı. Hemşirelik görevini Umman'da yerine getirmeye çalışan Jeanetta Boersma, özellikle bölge kadınları ile sıcak ilişkiler kurarak kadınların doğum yapmaları söz konusu olunca yaşanılabilecek sorunların önüne geçmek amacıyla ilişkilerini doğum sonrası süreci kapsayacak şekilde sürdürmekteydi. Yerel kadınlar ile yaptığı sohbet toplantılarında hastanenin önemine vurgu yaparak kadınları herhangi bir sağlı problemi ile karşılaşmaları anında oturup evde doktor misyonerin kendisini ziyaret etmesini beklemektense bir an önce 
hastaneye müracaat etmesini öğütlemekteydi. Bu öğüdün arkasında misyonun farklı amaçları da bulunmaktaydı. Doktor misyonerlerin beraberindeki yardımcı heyeti ile seyahat ederek harcanan çok zamanda az kişiye ulaşması bu uygulama sayesinde bitecek bundan sonra hastalar sabit olan doktoru ziyaret edeceklerdi. Diğer bir amaç ise misyon hastanelerinin ihtiyaçlarını karşılamak için az da olsa hastalardan alınacak katkı payı misyona maddi destek sağlayacaktı. Böyle bir geleneğin oluşması elbette hemen beklenemezdi fakat zamanla hastaneyi ziyaret eden hasta sayısında önemli bir artış söz konusuydu (Boersma, 1991: s. 84/86).

Umman'ın Muskat şehrindeki Amerikan misyon kadın hastanesi kendi alanında tekti. Kadın hastalıkları ile olan mücadelesinin yerel halk tarafından saygı ile karşılanmasının yanında hastaneden yararlanan gebe kadınlara doğum öncesi ve sonrası yapılması gerekenler hakkında özellikle hemşirelerin verdiği eğitim ile de adından söz ettirmekteydi. Yerel gebe kadınların doğum sonrası çocuk bakımı, sağlık bilgisi ve çocuk doğduktan sonra kadının kendisine olan bakımı hakkında hemşirelerin verdiği bilgiler bölgede bu konu hakkında bir bilinç oluşturması yönünde hastanenin rolü büyüktü. Misyon hastanesi, bölgede sağlık alanında verdiği hizmetin yanında yerel kadınlara iş imkânı da sunmaktaydı. Hemşireliğe, ebeliğe ve hasta bakıcılığına ilgi duyan bu alanda kendisini geliștirmek isteyen ve az da olsa bir miktar para kazanmak isteyen yerel kadınlardan bazıları hastanede ilgi duydukları alanlarda kendileri için sunulan firsatlardan yararlanarak istihdam edilmekteydi. Bu durum aynı zamanda hastanede çalışan misyonerler için bir fırsat meydana getirerek gün boyu yanı başında olan bu yardımcıları din değiştirme yönünde etkileme şansları da olabilmekteydi. Hastanede hemşire olarak görev yapan Jeanetta Boersma, yardımcılardan biri için kitabında genç bayanın bir Hristiyan olacakmış gibi yetiştirildiğinden bahsetmektedir (Boersma, 1991: s. 402-105). Jeanetta Boersma, Umman bölgesindeki Amerikan misyonunda 1980'li yıllara kadar hizmet verdi. Bölgenin değişimine tanık olan bu misyonerin hatıratı olan Grace in the Gulf adlı eseri bu nedenle önemlidir. Misyonda iki görevi olan Jeanetta Boersma, hem hastanede çalışarak hemşirelik vazifesini gerçekleştiriyordu hem de çevresindeki insanları Protestanlığa davet etmek için misyonerlik görevinde bulunuyordu fakat ne acıdır ki Protestanlığa kazandırdığı hiç kimse yoktu.

Arabistan misyonuna misyoner akışı 1950’li yıllarda da sürmekteydi. Misyonerler sadece Amerika'dan değil örgütün dünyanın değişik alanlarındaki merkezlerinden de misyonerlerin yer değişimi sağlanarak atamalar gerçekleştirilmekteydi. Bu atamaları yaparken örgüt bazen de kendisini mecbur hissetmekteydi bunun en önemli nedeni misyon merkezlerinin bulunduğu bazı ülkelerde misyonerlerin deşifre olmasıydı. 1950 yılında Umman'ın Muskat şehri, yeni misyonerlerin şehre girişine tanıklık etmekteydi. Bu misyonerlerden ikisi Anne De Young ve Jeanette Veldman adlı iki bayan misyonerdi. Çinli komünistlerin bu misyonerlerin gerçek niyetlerini ortaya çıkarıp ülkeden kovmadan önce bayan misyonerler misyonun Çin'deki teşkilatlanmasında görev yapmaktaydılar. Hemşirelik eğitimi almış olan bu misyonerler Umman'a gelerek Mutrah bölgesinde bir hemşire okulunun yapılanmasında görev alamaya başladılar. Ayrıca Umman misyonunun önemli kurumlarından biri olan kadın hastanesinde çalışan hemşireler de bu okulun eğitimine yardımcı olmaya başladılar. Okulda, bir yandan hemşirelik mesleğinin incelikleri öğretilirken bir yandan da mesleği seçenlerin uyması gereken kurallar ve Protestanlık ile harmanlanmış prosedürleri öğrenmeleri sağlanmaktaydı. Misyon hastane ve kliniklerinde iş gününün dua ile başlamasına dikkat edilir ve doktor bekleyen sıradaki hastaların arasında dolaşılarak İncil okunurdu (Al-Sayegh, 1998: 
s. 353/354).

Her ne kadar Amerikalı misyonerler Arabistan yarımadasının büyük bir bölümünü ziyaret etmiş olsalar da halen misyonun dokunmadığı alanlar da mevcuttu. Katar bu alanlardan biriydi. 1915 yılında ilk misyonerlerin Katarı ziyaret etmelerine rağmen misyonerlik faaliyeti adına kalıcı bir çalışma hiç yapılamamıştı. Ancak 1940 yılına gelindiğinde Katar şeyhinin ülkede bir hastane yapılması amacıyla misyonerleri davet etmesi üzerine Katar'da da Amerikan Protestan misyonerlik faaliyeti başladı. Örgüt, Katar'da kendisine tanınan avantajları kullanarak bir hastane meydana getirdikten sonra bu kuruma bir doktor ve bir hemşire atadı. Yıllar geçince bu kuruma yeni misyonerler ve başka misyonlardan yer değişimi için başvuruda bulunan misyonerler atanmaya başladı. Doktor Mary Allison, Jeanette Cornelia gibi önceki bölümlerde kendilerinden bahsettiğimiz misyonerler, misyonun yeni çalışma sahası olan Katar'a gelerek görev üstlendiler. Bu dönem zarfında da misyonerlerin Protestanlık propaganda faaliyetlerini genellikle sağlık hizmetleri ile birlikte yürüttükleri söylenebilir fakat misyonerlerin etkisi adam devşirmeden çok kültürel ve yerel kadınların sosyal haklarının gelişimi yönünde oldu (Bruggink, Baker, 2004).

Arabistan yarımadasındaki Amerikan Protestan misyonunun faaliyet sahalarından biri de Birleşik Arap Emirliği olarak bilinen bölgeydi. Bu bölgenin Protestan misyonerlik faaliyetlerine maruz kalması her ne kadar on dokuzuncu yüzyılın sonlarına doğru başlasa da bölgede genellikle erkek misyonerlerin yürüttügü propaganda faaliyetleri vuku bulmakta ve toplumun kadın kısmı arasında bayan misyonerlerin yokluğundan dolayı propaganda yapılamamaktaydı. Bayan misyonerlerin Birleşik Arap Emirliklerine yönelmesi ancak 1950'den sonra gerçekleşmeye başlayacaktı. Bölgeye gönderilen ilk bayan misyoner doktor olan Sarah Hosman adlı bir bayan misyonerdi. Sarah Hosman, 1911 yılında Arap misyonuna katılmış, Bahreyn'de Arap dil eğitimini tamamlayarak misyonun farklı alanlarında uzun süreler görevde bulunmuş en son olarak da Umman misyonuna dâhil edilmiş ve buradan Birleşik Arap Emirlikleri bölgesine tayin edilmişti (Neglected Arabia 1913). 1948'de Birleşik Arap Emirlikleri bölgesine intikal eden Sarah Hosman, hemșire arkadaşı Bayan Mary Barter ile birlikte bu bölgenin iç kısımlarında, merkezi otoriteden uzak yerel kadınlar arasında rahat çalışabilecekleri bir alanda ufak çaplı bir hastane kurmakla işe propaganda faaliyetlerine başlamayı hedeflemekteydi. Ülkenin Ajmin şehrini merkez olarak seçen Sarah Hosman, bu şehri misyonun bu ülkedeki merkez istasyonu olarak kabul ederek kariyerine bu noktadan başlamayı kararlaştırdı. Bu kararı alırken Ajmin'deki şeyh de etkili oldu. Şeyh'in hastane için yer tahsisi konusundaki yardım sözünü içeren mektubu Hosman’ın belli bir süre bu bölgede kalarak gerekli olan binanın kendisine tahsis edilmesini bekledi. Bu bekleyiş sırasında komşu şehir olan Sarjah'ın Şeyhi, karısını tedavi ettirmek için Doktor Sarah Hosman ile iletişim kurarak kendisini bu şehre davet etti (Neglected Arabia 1939). Hastane için gerekli bina ve arsayı misyonere sağlayan Şeyh, misyonun bu şehirde kurulmasında büyük rol oynadı. Şehirde Sarah Hosman Hastanesi adıyla kurulan misyon hastanesi ancak 1952 yılında hasta kabul edebilecek bir seviyeye ulaştı. Misyon hastanesi yine bir kadın hastanesiydi, açıldıktan sonra hemen tedavi hizmetlerine başlayan hastane, yerel kadınlardan oldukça ilgi görmekteydi. Hastanenin her gün ki açılışında dualar okunmaktaydı. Dua seremonisine katılmayanlara tedavi uygulanmamaktaydı (Political diaries of the Gulf, 1990: 16). Bu uygulama ile Protestanlık propagandası yaptığını düşünen hastanedeki Amerikalı misyonerler, yarımadanın diğer bölgelerinde çalıșan meslektaşlarının adam devşirmede yaşadığı başarısızlığın aynısını yaşayarak uzun yıllar sonunda bile misyon merkezi olan Amerika'ya Protestanlı̆̆ı kabul 
etmiş bir Müslümanı rapor edemeyeceklerdi. Ancak bölge halkı üzerindeki etkileri genellikle kültürel olarak kalacaktı (Political diaries of the Gulf, 1990: s. 16).

Suudi Arabistan'ın iç kesimleri de Protestan misyonerlik faaliyetlerinden nasibini alan sahalar arasında gösterilebilir. Arabistan misyonunun temel hedefi de Arap yarımadasının tümüyle Protestanlığa kazandırılması olduğu için yarımadanın iç kesimlerine dokunulmadan bu hedefin gerçekleşmeyeceği misyonerler arasında var olan bir olguydu. 1950'den önce misyonerler iç kısımlara seyahatler düzenlemiști. Bu seyahatlere kadın misyonerler de dâhil olmuş ziyaret edilen alanlarda uzun süreli tedavi yapamamış fakat ilaç yardımlarında bulunarak bölgenin fizibilite çalışmasını yapıp gelecekte bu bölgede oluşturulması planlanan misyon istasyonlarının hangi alanlarda kurulabileceğinin raporlarını tutmuşlardı. Bu seyahatlerde görev alan Doktor Nykerk ve karısı Rose Nykerk, özellikle Hufuf şehrinin önemli bir alan olduğunu misyon merkezinin bu şehirde kurularak Arabistan yarımadasının önemli şehirleri olan Riyad, Taif ve el Hassa gibi şehirler bu merkezden yapılacak yardımlar ile misyonerlerce fethedilebileceğini belirtmekteydi (Boersma, 1991: s. 5/8).

Kadın misyonerler, Arabistan misyonunun gelişiminde ve yerel halk üzerinde etki sahibi olmasında önemli rol oynadılar ve bu rolleri 1960’lı yıllara kadar devam etti. 1970'li yıllarda bölgede özellikle petrolden kaynaklanan ekonomik ve siyasi değişiklikler Amerikan misyonun gelişiminde hem olumlu hem de olumsuz katkı yaptı. Körfez ülkeleri üzerindeki İngiltere hegemonyasının kalkması ile birlikte bir zenginleşme yaşanmaya başladı. Petrol ile gelen bu zenginlik bölgenin birden bire kalkınmasına neden olmasına rağmen gelenekselleşmiş Arap yaşamı nerdeyse hep aynı kaldı. Ancak bölgenin her şehrinde okul, hastane ve klinikler inşa edilmeye başlandı. Misyon okul ve hastanelerinde görev alan yerel kadınlar bu tür kurumlarda da çalışarak kadının bu kurumların gelişmesindeki rolünün idareciler tarafından onanmasının yolunu açtılar. Misyoner okullarında dil eğitimi de alan yerel kız çocukları, teknolojinin bölgeye girmesiyle beraber radyo, televizyon, gazete ve dergi gibi yayın faaliyetlerini bünyesinde toplayan iletişim sektörünün ortaya çıkmasında rol oynadılar (Boersma, 1991: s. 180/183). Basra Körfezi'ne komşu olan Arap devletleri eğitim ve sağlık alanında misyoner yapılanmasını örnek alarak eğitim ve sağlık sistemlerini kurmaya çalıştılar ve misyonerler ile olan işbirliklerini de sürdürmeye uzun yıllar devam ettiler.

\section{Sonuç}

Arabistan yarımadasının büyük bir bölümünde etkili olan ve yoğun olarak da Basra Körfezi çevresinde konuşlanan Amerikan Protestan misyonunda görevli kadın misyonerlerin bölgenin yerel kadınları arasında sürdürdükleri misyonerlik faaliyetlerinin etkisini tartıştığımız bu çalışmada misyonun başarılı veya başarısız olduğu kanaatine varmanın güç olduğunu söylemekte yarar vardır. Misyon sahasında Protestanlığı benimseyenlerin nerdeyse hiç olmaması ile birlikte bölgedeki hiç bir ülkenin Hristiyanlığı topluca kabul ettiği gerçekleşmemiştir. Bu açıdan misyonun başarısız olduğu kabul edinilebilinir ancak bölgenin kültürel ve sosyal değişimi üzerindeki etkisi tartışmasızdır. İslam dininin bölgede derin ve kuvvetli köklere sahip olması misyonun dini açıdan başarısızlığa uğramasında rol oynaması kuvvetli bir olasılıktır. Bu durumu bölgede görev yapan misyonerler de dile getirmiş olup dini faaliyetler ile sahadaki toplumu etkilemeyeceklerinin farkında olarak toplumu kazanmak için daha çok eğitim ve sağlık alanına yönelmeleri bu nedene bağlanabilir. Kadının Arap toplumu içerisindeki konumunu iyi analiz eden misyonerler, ailede anneyi kazanmanın misyon için 
meydana getireceği avantajları tasavvur ederek toplumun kadın kesimine yönelmesi ve geleceğin anne adayları olacak kız çocuklarını etkilemekle bölgede Protestan neslin temelini atmayı planlamaktaydılar.

Kadın misyonerlerin Arabistan misyonuna katılmaya başlaması ile halk ile sağlanan iletişim misyonerlerin toplumun temel çekirdeği olan aile ile bağlantı kurmasını sağlayarak misyonun bölgede Protestan varlığının temellerini atmasında yardımcı oldu. Dünyanın bu bölgesinde farklı bir propaganda stratejisi izlemek zorunda kalan Protestan misyonerler, halkın temel ihtiyacı olan sağlık alanındaki hizmetlere yoğunlaşarak bu açıdan toplumu etkilemeye çalıştılar. Erkek misyonerlerin belli bir yere kadar ilerlemesine müsaade eden toplumsal yapının kültür ve gelenekleri misyona özellikle doktor ve hemşire gibi kadın misyonerlerin dahil edilmesiyle aşılmaya çalışıldı. Kadın misyonerlerin özverili ve adanmışlık ruhuyla elde ettiği başarılar Arabistan misyonunun Arap yarımadasının geniş alanlarına yayılmasını mümkün kılarken bu başarıların Amerika'da da iki türlü dönütün oluşmasını ve Arabistan'a akmasını sağladı. Bu dönütlerden biri bağış diğeri ise genç, alanında uzman ve yetenekli bekar bayan misyonerlerin misyon sahasına yönlenmesine neden oldu.

Arap kadının sosyal statüsünde olumlu katkılar sağlayan kadın misyonerler, bu coğrafyada kadına olan bakışın değișiminde örnek rol görevi üstlenerek eğitim sayesinde kadının hangi statülere ulaşabileceğinin birer canlı temsili oldular. Kadın misyonerler sayesinde Arap toplumunun misyonerlere karşı bakışı olumlu yönde değișerek misyonerler ile halk arasında sıcak bir atmosferin oluşması sağlandı. Kız çocuklarının eğitimine büyük önem veren misyonerler her ne kadar geleceğin Protestan annelerini yetiştirdiklerini düşünsellerde Petrol ile birlikte bu coğrafyada meydana gelen siyasi ve ekonomik gelişmeler yetiștirilen bu çocukların Protestanlıktan çok yaşadıkları alanın sanayileşmesinde ve çağdaşlaşmasında önemli rol üstlenebileceklerini görüp Protestanlık yerine batının egemenliğini kabul etmiş ona özlemle bakan nesillerin yetişmesine çalıștılar. Kadın misyonerlerin sağlık alanındaki faaliyetleri sonucu kurdukları hastaneler ve kliniklerde uyguladıkları sistemler örnek alınarak bölgedeki sağlık sektörünün temeli atıldı. Misyonerlerin bu kurumlarda istihdam ettiği yerel yardımcılar da bu sektörün gelişmesinde rol oynadılar (Greenberg, 2010: s. 21).

Arabistan misyonunda görevli kadın misyonerlerin meydana getirdiği literatür de bölgenin tarihi ve sosyal değișimi hakkında önemli bilgiler sunmaktadır. Farklı zamanlarda farklı mekânlarda bulunan kadın misyonerler, deneyimlerini yazdıkları hatıratlarda Arabistan yarımadasının kültür, gelenek ve yaşam koşullarını tasvir ederken aynı zamanda misyonun sorun ve çözümlerine de entelektüel bir kimlik ile değinerek sonraki aşamaların tespitini de yapmaktan çekinmemişlerdi. 


\section{Kaynakça}

Akgün, S. Karal (2014). Osmanlı Imparatorluğu'nda Mormon Misyonerler. 1. Baskl. İstanbul: Türkiye İș Bankası Kültür Yayınları.

Allison, M. Bruins; Shaw, S. (1994). Doctor Mary in ArabiaMemoirs. 1st ed. Austin: University of Texas Press.

Al-Sayegh, F. H. (1998) "American women missionaries in the Gulf: Agents for cultural change", Islam and Christian-Muslim Relations, Sayı: 3, Cilt 9, 339-356.

Boersma, J. (1991). Grace in the GulfThe Autobiography of Jeanette Boersma, Missionary Nurse in Iraq and the Sultanate of Oman. Michigan: Eerdmans Publishing. Available online at https://books.google.com.tr/books?id=M0bEKhZ1aWkC.

Brouwer, R. Compton (1990). New Women for GodCanadian Presbyterian Women and India Missions, 1876-1914. Toronto, Buffalo: University of Toronto Press (Social history of Canada, 44).

Bruggink, D. J.; Baker, K. N. (2004). By Grace AloneStories of the Reformed Church in America. Grand Rapids, Mich. [u.a.]: Eerdmans (The historical series of the Reformed Church in America, 44).

Calverley, E. (1958). My Arabian Days and Nights. New York: Thomas Y. Crowell Company. Available online at https://archive.org/stream/myarabiandaysnig00calv\#page/ n7/mode/2up.

Dalenberg, C. (1989). Mudhakkirat Sharifa al-Amrikdniya. Bahreyn: Bilinmiyor.

Dalyan, M. G. (2011) “Amerikan Misyonerliğinde Kadın ve Kadının Rolü”, Ortadoğu Örneği", Turkish Studies, Sayl: 2, Cilt 6, 341-358, checked on 11/14/2013.

Greenberg, E. (2010). Preparing the Mothers of TomorrowEducation and Islam in Mandate Palesitine. Austin: University of Texas Press.

Mason, A.; Barny, F. (1926). The History of the Arabian Mission. New York: The Board of foreign missions, Reformed church in America. Available online at https://archive.org/ details/MN41708ucmf_4.

Missionary Review Publishing Co (1911). Missionary Review of the World. Available online at https://catalog.hathitrust.org/Record/000049753.

Neglected Arabia (1913). Yale Divinity Library, 87. Available online at file://C:/Users/ Acer-PC/Downloads/digcoll_439220.pdf.

Neglected Arabia (1939). Yale Divinity Library, 185. Available online at http://search. library.yale.edu/. 
Political diaries of the Gulf (1990). 16 volumes. Slough: Archive Editions.

Scudder, L. R. (1998). The Arabian Mission's StoryIn search of Abraham's Other Son. Grand Rapids, Mich., Cambridge: Eerdmans (The historical series of the Reformed Church in America, no.30).

Storm, H. (1938). Whither Arabia?A Survey of Missionardy Oppurtunity. USA: World Dominion Press.

Tuson, P. (2003). Playing the GameWestern Women in Arabia: Palgrave Macmillan. Available online at https://books.google.com.tr/books?id=sWX9GoHX46QC.

Ümit, D. (2014) "The American Protestant Missionary Network in Ottoman Turkey, 1876-1914", International Journal of Humanities and Social Science, Sayl: 6 (1), Cilt 4, 16-51.

Van Den Berg, H. W. (2005). Nineteenth-Century Protestant Missions and Middle Eastern Women: An Overview. In Inger Marie Okkenhaug, Ingvild Flaskerud (Eds.): Gender, Religion and Change in the Middle East. Two Hundered Years of History. New York: Berg, 103-122.

Vander Werff, L. L. (1977). Christian Mission to Muslims: The RecordAnglican and Reformed Approaches in India and the Near East, 1800-1938: William Carey Library. Available online at https://books.google.com.tr/books?id=NuStj-saoQkC.

Windsor, L. L. (2002). Women in Medicine: An Encyclopedia: ABC-CLIO. Available online at https://books.google.com.tr/books?id=QtZtkf35CF0C.

Zwemer, S. Marinus (1900). Arabia; the Cradle of Islam. New York: F. H. Revell Company. Available online at https://archive.org/details/arabiacradleofis01zwem. 